\title{
Temporal change in the molluscan assemblages (bivalves and gastropods) of Frobisher Bay, Nunavut, Canada, over 50 years
}

\author{
Erin C. Herder, Alec Aitken, and Evan Edinger
}

\begin{abstract}
Long-term studies provide an effective way to assess the ecological impacts of decades-long environmental change in Arctic coastal benthic environments, but are rarely undertaken in the Canadian Arctic. In light of this, historical datasets can be compared with modern samples to examine temporal differences in benthic community structure. Frobisher Bay, Nunavut, provides a unique opportunity to use a historical census to examine the impacts that long-term environmental changes have had on the marine benthos. Between 1967 and 1976, and in 2016, infaunal samples were collected in inner Frobisher Bay and were compared to determine how the molluscan assemblages have changed between the two time periods. Molluscan assemblages in two regions of inner Frobisher Bay (Iqaluit and Cairn Island) were examined to minimize sampling discrepancies between the two time periods. A long-term increase in mean annual air temperature and a decline in the length of the ice cover season were observed. Both regions exhibited some change in sediment composition and quality as well as in molluscan assemblage between the two time periods, and species diversity indices also indicated some change between these time periods. Both the 1967-1976 and 2016 molluscan datasets provide a baseline for future long-term studies in a changing Arctic.
\end{abstract}

Key words: long-term ecology, temporal change, molluscs, benthic communities, Frobisher Bay.

Résumé : Les études à long terme constituent un moyen efficace d'évaluer les impacts écologiques des changements environnementaux survenus au cours des décennies dans les milieux benthiques côtiers arctiques, mais elles sont rarement entreprises dans l'Arctique canadien. Dans ce contexte, les ensembles de données historiques peuvent être comparés à des échantillons modernes pour examiner les différences temporelles dans la structure des communautés benthiques. La baie de Frobisher, au Nunavut, offre une occasion unique d'utiliser un recensement historique pour examiner les impacts que les changements environnementaux à long terme ont eus sur le benthos marin. Entre 1967-1976 et 2016, des échantillons benthiques ont été collectés à l'intérieur de la baie de Frobisher et ont été comparés pour déterminer comment les assemblages de mollusques ont changé entre les deux périodes. Les assemblages de mollusques de deux régions de l'intérieur de la baie de Frobisher (Iqaluit et l'île Cairn) ont été examinés afin de minimiser les écarts d'échantillonnage entre les deux périodes. On a observé une augmentation à long terme de la température annuelle moyenne de l'air et un déclin de la durée de la saison de couverture de glace. Les deux régions ont montré un certain changement dans la composition et la qualité des sédiments et dans l'assemblage des mollusques entre les deux périodes, et les

Received 30 September 2020. Accepted 2 April 2021.

E.C. Herder and E. Edinger. Memorial University of Newfoundland, Department of Geography, St. John's, NL A1B 3X9, Canada.

A. Aitken. University of Saskatchewan, Geography \& Planning, 117 Science Place, Saskatoon, SK S7N 5C8, Canada. Corresponding author: Erin C. Herder (email: erin.herder@dfo-mpo.gc.ca).

(C) 2021 The Author(s). This work is licensed under a Creative Commons Attribution 4.0 International License (CC BY 4.0), which permits unrestricted use, distribution, and reproduction in any medium, provided the original author(s) and source are credited. 
indices de diversité des espèces ont également indiqué un certain changement entre les périodes. Les ensembles de données sur les mollusques de 1967-1976 et de 2016 constituent une base de référence pour les futures études à long terme dans un Arctique en mutation. [Traduit par la Rédaction]

Mots-clés : écologie à long terme, changement temporel, mollusques, communautés benthiques, baie de Frobisher.

\section{Introduction}

The circumpolar Arctic is currently warming at a rate twice that of the global mean temperature (Overland et al. 2017), and sea ice extent has declined markedly over the past 30 years (Forbes 2011; McLaughlin et al. 2011; Richter-Menge et al. 2017). With the increasing concern around climate warming and its predicted impacts on Arctic continental shelf benthos (Carmack and McLaughlin 2001; Piepenburg 2005), there is a growing consensus that long-term studies are required to monitor changes in the benthic community. Many authors have called for such studies (e.g., Cusson et al. 2007; Renaud et al. 2007; Brown et al. 2011; Wassmann et al. 2011; Grebmeier 2012; Kortsch et al. 2012; Renaud et al. 2015; Thurstan et al. 2015) to understand how benthic communities are linked to environmental processes and how future climate change may influence their distribution, composition, and function (Loeng 2005; Carroll et al. 2008). Several authors have confirmed the need for sampling on decadal scales to examine long-term community level changes in the marine benthos (Cusson et al. 2007; Renaud et al. 2007). Unfortunately, in Arctic environments, gaining access to the same study area year after year can be extremely challenging due to cost and accessibility. This is particularly true in the Canadian Arctic, where sea ice can restrict accessibility for repeated sampling (Carey 1991). Long-term benthic community studies have occurred throughout the circumpolar Arctic, but there are very few studies that have examined long-term benthic community change in the Canadian Arctic (Fig. 1). Historical ecological research provides a valuable source of data that can be compared directly with modern sampling through a comparative sampling design to assess long-term change in benthic community structure and function.

Marine molluscs (bivalves and gastropods) represent an excellent group of organisms with which to examine long-term environmental change. Marine molluscs are abundant in benthic communities (Carey et al. 1984; Carroll et al. 2009; Clarke and Crame 2010), have limited mobility, and are long-lived, some living upwards of 30+ years (Andrews 1972; Powell and Cummins 1985; Carroll et al. 2009; Moss et al. 2017; Moss et al. 2018; Chikina et al. 2020). Molluscs have been used previously as indicators of environmental change, and they have also been used to infer change in whole benthic communities (Dyke et al. 1996; Dimitriadis and Koutsoubas 2008; Novoa et al. 2016; Chikina et al. 2020). By examining changes that have occurred in marine mollusc assemblages on a multidecadal time-scale, long-term trends may emerge at time scales comparable to climate normals.

Frobisher Bay, located along the southeastern coast of Baffin Island, Canada, has experienced similar long-term environmental changes as the circumpolar Arctic, including warming surface air temperatures and declining thickness and extent of sea ice (Government of Canada 2017, 2018a). This region has also experienced rapid population growth and urban development in the coastal city of Iqaluit, including the current development of a deep-sea port at Inuit Head (Fig. 2). Between 1967 and 1976, benthic sediment and infaunal samples were collected in the coastal waters of inner Frobisher Bay (Wacasey et al. 1979, 1980). We re-sampled these same stations in 2016 to examine how seabed habitat and the composition and function of molluscan assemblages have changed over the last 50 years. 
Fig. 1. Coverage of long-term studies throughout the Arctic Seas. Map created with ESRI ArcMap 10.4, base map derived from Natural Earth (2020). References cited: Beuchel and Gulliksen 2008; Carroll et al. 2009; Chikina et al. 2020; Cross et al. 1987; Cross and Thomson 1987; Dyer et al. 1984; Grebmeier et al. 2006, 2015; Kedra et al. 2010; Kiyko and Pegrebov 1997; Kortsch et al. 2012; Kozlovskiy et al. 2011; Renaud et al. 2007; Taylor et al. 2017.

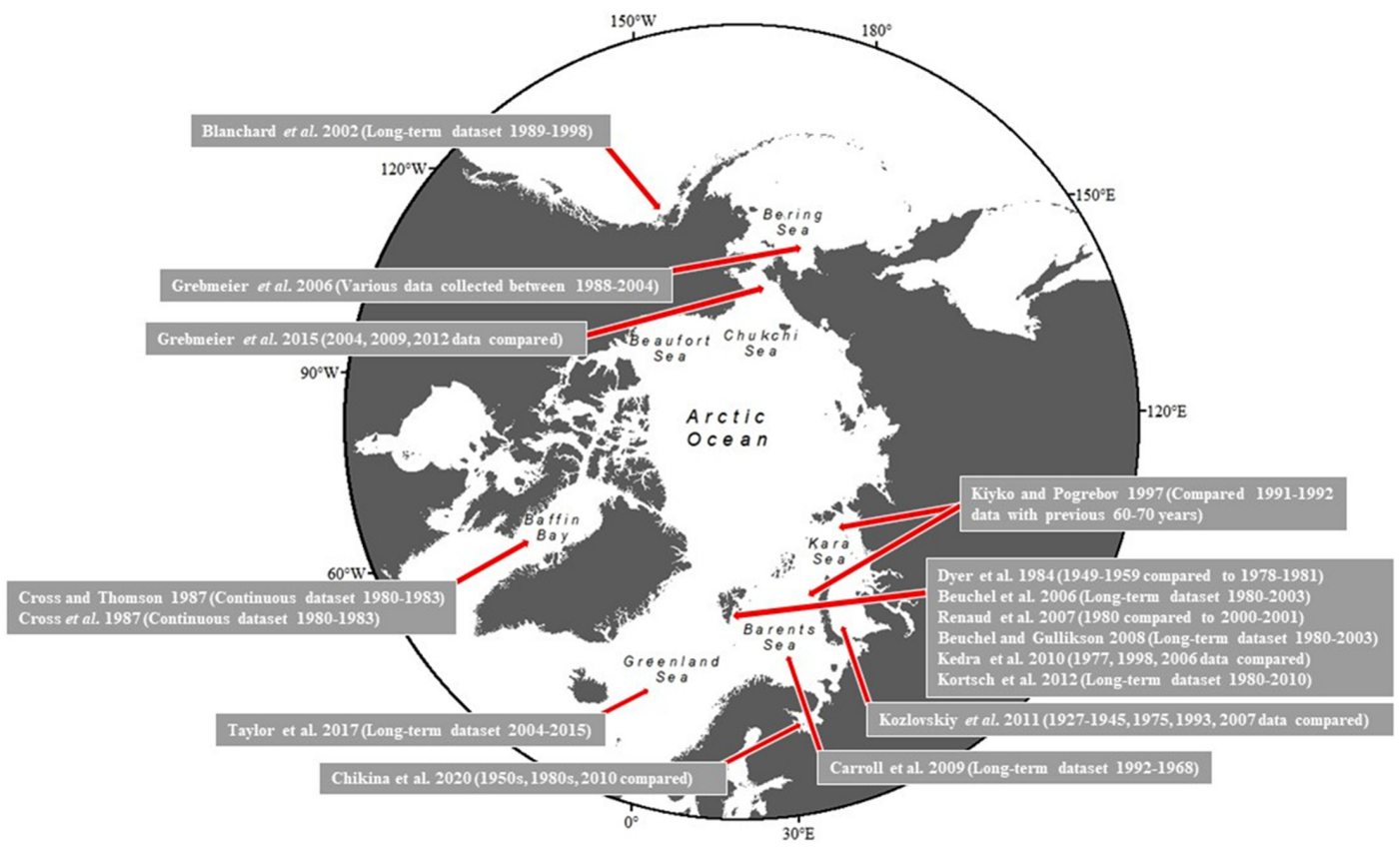

\section{Materials and methods}

\section{Study area}

Frobisher Bay extends approximately $265 \mathrm{~km}$ to its junction with the northern Labrador Sea. The inner portion of Frobisher Bay reaches a maximum depth of $272 \mathrm{~m}$ (Hodgson 2005) and is covered by sea ice for most of the year. Ice formation typically begins around November and break-up typically occurs in July (Canadian Ice Service 2013). Stations sampled in this study were located approximately $2 \mathrm{~km}$ south of Iqaluit, herein referred to as the Iqaluit stations, and approximately $10 \mathrm{~km}$ southeast of Iqaluit near Cairn Island herein, referred to as the Cairn Island stations (Fig. 2). The Sylvia Grinnell River is located approximately $2.5 \mathrm{~km}$ west of the Iqaluit stations and approximately $10 \mathrm{~km}$ north-west of the Cairn Island stations. The Apex River is located approximately $3 \mathrm{~km}$ east of the Iqaluit stations and approximately $7 \mathrm{~km}$ north of the Cairn Island stations. Both of these rivers provide a local source of fresh water and sediment input into Frobisher Bay in the vicinity of the study area.

Five stations were sampled in the Iqaluit region, and six stations were sampled in the Cairn Island region. Geographic coordinates provided by Wacasey et al. $(1979,1980)$ for the historical data proved to be inaccurate (e.g., some coordinates were located on land); therefore, the maps provided in the historical documents were geo-referenced in ESRI ArcMap 10.4.1 to obtain the most accurate station locations for re-sampling in 2016. This method came with an inherent risk of spatial inaccuracy, which could have resulted in different depths being sampled at each station between the two time periods. This issue is addressed throughout the manuscript. 
Fig. 2. Location of long-term ecology stations sampled in Frobisher Bay, Nunavut, between 1967 and 1976 and in 2016 (a) with an inset map of Baffin Island $(b)$ and Frobisher Bay $(c)$. Map and basemap created in ESRI ArcMap 10.4.

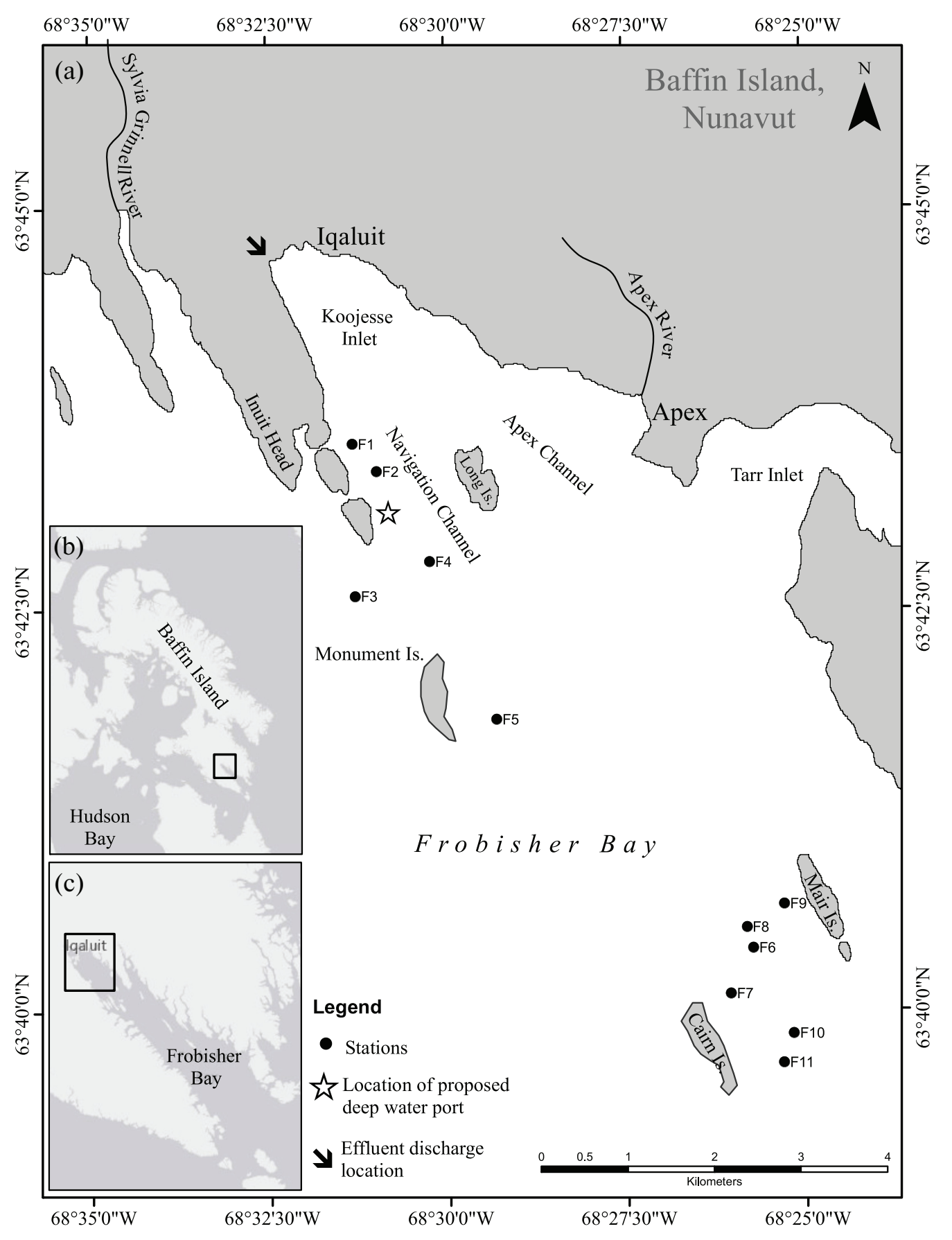

- Published by Canadian Science Publishing 


\section{Long-term environmental data}

Long-term environmental data collected in the study area include surface air temperature, ice thickness and extent, and river discharge rates for both the Sylvia Grinnell and Apex rivers. Historical air temperature data were collected between 1967 and 2017 (Government of Canada 2018a) in the city of Iqaluit $\left(63^{\circ} 45^{\prime} 00.00^{\prime \prime} \mathrm{N}, 68^{\circ} 33^{\prime} 0.00^{\prime \prime} \mathrm{W}\right)$ and were examined for warming air temperature trends. Mean annual air temperature was calculated from average monthly temperature data. Historical ice thickness data were collected in Frobisher Bay between 1967 and 2016 through the Canadian Ice Thickness Program, and were examined for changes in ice thickness and to determine the length of the ice cover season in Frobisher Bay (Government of Canada 2017). Maximum ice thickness for each year was determined based on weekly ice thickness measurements. The length of the ice cover season was measured as the number of days it was safe to walk on the ice to take a thickness measurement (Government of Canada 2017). Historical hydrometric data for the Sylvia Grinnell River and Apex River were collected between 1971 and 2015 (Government of Canada 2018b). Average monthly discharge rates for the months of June through September were examined for changes in river discharge over time.

\section{Sediment and infaunal sampling}

Historical (1967-1976) benthic sediment and infaunal samples were collected at 11 stations using a Petersen grab (surface area $0.065 \mathrm{~m}^{2}$ ) from the M.V. Calanus (Wacasey et al. 1979, 1980). These same stations were re-sampled in 2016 using a Van Veen grab (surface area $0.111 \mathrm{~m}^{2}$ ) from the M.V. Nulialjuk in the coastal waters of Frobisher Bay (Table 1; Fig. 2). Three grabs at station F1 and one grab at F3 were collected with a Petite Ponar grab (surface area $0.024 \mathrm{~m}^{2}$ ) because the Van Veen was unsuccessful in recovering a sample.

Wacasey et al. $(1979,1980)$ collected between 4 and 6 grabs at each station, and these replicate grabs were combined together (total surface area $0.26-0.39 \mathrm{~m}^{2}$ ) to form a single sample for each station. Stations F1, F2, F6, and F7 were sampled more than once between 1967 and 1976, which provided both seasonal and interannual data for these stations. A total of 112 grabs were pooled into 20 samples, and an additional two grabs were collected at two stations for sediment only. The data reports prepared by Wacasey et al. $(1979,1980)$ included only the combined data, making examination of individual grabs impossible. This method conceals the within-grab variability that is common in heterogeneous or patchy systems, and effectively homogenizes the station sample (Arctic Laboratories Ltd. 1985; Carey and Keough 2002). These same 11 stations were re-sampled in 2016, and 2-3 grabs were collected at each station. To be comparable with the historical data, the data from the replicate grabs were combined (total surface area $0.072-0.333 \mathrm{~m}^{2}$ ). A total of 32 grabs were combined into 11 samples (Table 1). Station details for each historical sample included in this study, as well as individual grabs collected at each station in 2016, can be found in the Supplementary data, Table $S 1^{1}$. Historical and modern infaunal samples were washed over a $0.5 \mathrm{~mm}$ sieve, and bivalves and gastropods from each grab were identified to the lowest taxonomic level, with $85 \%$ of individuals from the historical samples identified to the species level and $80 \%$ of the modern samples identified to the species level. Wacasey et al. $(1979,1980)$ collected infaunal samples throughout the year but for this study, only historical samples collected when the bay was free of sea ice (between July and October) were compared with the

${ }^{1}$ Supplementary data are available with the article at https://doi.org/10.1139/as-2020-0037.

- Published by Canadian Science Publishing 
Table 1. Summary of samples collected in Frobisher Bay between 1967 and 1976 by Wacasey et al. $(1979,1980)$ and in 2016.

\begin{tabular}{|c|c|c|c|c|c|c|c|c|c|c|c|c|c|c|c|}
\hline Station $^{a}$ & $\begin{array}{l}\text { Date } \\
\text { sampled }\end{array}$ & $\begin{array}{l}\text { Latitude } \\
\left({ }^{\circ} \mathrm{N}\right)^{b}\end{array}$ & $\begin{array}{l}\text { Longitude } \\
\left({ }^{\circ} \mathrm{W}\right)^{b}\end{array}$ & $\begin{array}{l}\text { Depth } \\
(\mathrm{m})^{c}\end{array}$ & $\begin{array}{l}\text { Sed. } \\
\text { sample }\end{array}$ & $\begin{array}{l}\text { No. grabs } \\
\text { pooled }\end{array}$ & $\begin{array}{l}\text { Total } \\
\text { surface } \\
\text { area }\left(\mathrm{m}^{2}\right)\end{array}$ & Station $^{a}$ & $\begin{array}{l}\text { Date } \\
\text { sampled }\end{array}$ & $\begin{array}{l}\text { Latitude } \\
\left({ }^{\circ} \mathrm{N}\right)^{b}\end{array}$ & $\begin{array}{l}\text { Longitude } \\
\left({ }^{\circ} \mathrm{W}\right)^{b}\end{array}$ & $\begin{array}{l}\text { Depth } \\
(\mathrm{m})^{c}\end{array}$ & $\begin{array}{l}\text { Sed. } \\
\text { sample }\end{array}$ & $\begin{array}{l}\text { No. } \\
\text { grabs } \\
\text { pooled }\end{array}$ & $\begin{array}{l}\text { Total } \\
\text { surface } \\
\text { area }\left(\mathrm{m}^{2}\right)\end{array}$ \\
\hline \multicolumn{8}{|c|}{ Cairn Island Stations } & \multicolumn{8}{|c|}{ Iqaluit Stations } \\
\hline F6 (5) & 23-Jul-68 & $63^{\circ} 40^{\prime} 23.2$ & $68^{\circ} 25^{\prime} 44.0$ & 45 & No & 6 & 0.39 & F1 (5b) & 29-Jul-69 & $63^{\circ} 43^{\prime} 32.2$ & $68^{\circ} 31^{\prime} 18.5$ & 15 & No & 6 & 0.39 \\
\hline F6 (5) & 20-Aug-68 & & & 60 & Yes & 6 & 0.39 & $\mathrm{~F} 1(5 \mathrm{~b})$ & 3-Sep-69 & & & 15 & Yes & 6 & 0.39 \\
\hline F6 (5) & 3-Sep-68 & & & 60 & No & 6 & 0.39 & $F 1(5 b)$ & 8-Aug-73 & & & 14 & Yes & 5 & 0.325 \\
\hline F6 (5) & 8 -Oct-68 & & & 62 & No & 6 & 0.39 & $\mathrm{~F} 1(5 \mathrm{~b})$ & 19-Aug-76 & & & 14 & Yes & 5 & 0.325 \\
\hline F6 (5) & 2-Sep-69 & & & 53 & Yes & Not collected & & $\mathrm{F} 1^{*}$ & 10-Oct-16 & $63^{\circ} 43^{\prime} 32.0$ & $68^{\circ} 31^{\prime} 15.4$ & 11.5 & Yes & 3 & 0.072 \\
\hline F6 (5) & 6-Aug-70 & & & 72 & No & 6 & 0.39 & & & & & & & & \\
\hline \multirow[t]{2}{*}{ F6 } & 14-Oct-16 & $63^{\circ} 40^{\prime} 22.5$ & $68^{\circ} 25^{\prime} 45.8$ & 57.3 & Yes & 3 & 0.333 & F2 (25) & 8-Aug-73 & $63^{\circ} 43^{\prime} 21.7$ & $68^{\circ} 30^{\prime} 58.3$ & 30 & Yes & 5 & 0.325 \\
\hline & & & & & & & & F2 (25) & 18-Aug-76 & & & 28 & Yes & 5 & 0.325 \\
\hline F7 (5a) & 1-Aug-68 & $63^{\circ} 40^{\prime} 5.9$ & $68^{\circ} 26^{\prime} 3.1$ & 26 & Yes & 6 & 0.39 & F2 & 10-Oct-16 & $63^{\circ} 43^{\prime} 21.7$ & $68^{\circ} 30^{\prime} 58.6$ & 27.9 & Yes & 3 & 0.333 \\
\hline F7 (5a) & 20-Aug-68 & & & 32 & No & 6 & 0.39 & & & & & & & & \\
\hline F7 (5a) & 2-Sep-69 & & & 36 & Yes & Not collected & & F3 (28) & 13-Aug-73 & $63^{\circ} 42^{\prime} 35.3$ & $68^{\circ} 31^{\prime} 17.0$ & 30 & Yes & 4 & 0.26 \\
\hline F7 & 14-Oct-16 & $63^{\circ} 40^{\prime} 6.0$ & $68^{\circ} 26^{\prime} 0.9$ & 69.1 & Yes & 3 & 0.333 & F3 & 10-Oct-16 & $63^{\circ} 42^{\prime} 35.9$ & $68^{\circ} 31^{\prime} 15.9$ & 10.7 & Yes & 3 & 0.218 \\
\hline F8 (5e) & 23-Aug-69 & $63^{\circ} 40^{\prime} 30.7$ & $68^{\circ} 25^{\prime} 49.4$ & 58 & Yes & 6 & 0.39 & F4 (26) & 8-Aug-73 & $63^{\circ} 42^{\prime} 48.2$ & $68^{\circ} 30^{\prime} 14.0$ & 40 & Yes & 5 & 0.325 \\
\hline F8 & 11-Oct-16 & $63^{\circ} 40^{\prime} 32.4$ & $68^{\circ} 25^{\prime} 49.1$ & 53.8 & Yes & 3 & 0.333 & F4 & 10-Oct-16 & $63^{\circ} 42^{\prime} 45.9$ & $68^{\circ} 30^{\prime} 11.2$ & 36.3 & Yes & 3 & 0.333 \\
\hline F9 (5d) & 23-Aug-69 & $63^{\circ} 40^{\prime} 39.4$ & $68^{\circ} 25^{\prime} 17.8$ & 43 & Yes & 6 & 0.39 & F5 (27) & 8-Aug-73 & $63^{\circ} 41^{\prime} 48.8$ & $68^{\circ} 29^{\prime} 18.6$ & 43 & Yes & 5 & 0.325 \\
\hline F9 & 11-Oct-16 & $63^{\circ} 40^{\prime} 39.3$ & $68^{\circ} 25^{\prime} 15.3$ & 25.3 & Yes & 3 & 0.333 & F5 & 10-Oct-16 & $63^{\circ} 41^{\prime} 48.8$ & $68^{\circ} 29^{\prime} 21.2$ & 31.6 & Yes & 3 & 0.333 \\
\hline F10 (5f) & 23-Aug-69 & $63^{\circ} 39.8^{\prime}$ & $68^{\circ} 26.1^{\prime}$ & 73 & Yes & 6 & 0.39 & & & & & & & & \\
\hline F10 & 11-Oct-16 & $63^{\circ} 39^{\prime} 50.2$ & $68^{\circ} 25^{\prime} 10.6$ & 89.6 & Yes & 2 & 0.167 & & & & & & & & \\
\hline F11 (5c) & 23-Aug-69 & $63^{\circ} 39^{\prime} 40.0$ & $68^{\circ} 25^{\prime} 19.2$ & 31 & Yes & 6 & 0.39 & & & & & & & & \\
\hline F11 & 11-Oct-16 & $63^{\circ} 39^{\prime} 39.8$ & $68^{\circ} 25^{\prime} 17.8$ & 72.5 & Yes & 3 & 0.333 & & & & & & & & \\
\hline
\end{tabular}

Note: *All 2016 samples were collected with a Van Veen grab except for station F1 and one of the three grabs collected at F3, which were collected with a Petite Ponar grab.

${ }^{a}$ Station names in brackets reflect historical station naming system used by Wacasey et al. $(1979,1980)$.

${ }^{b}$ Latitude and longitude were recorded only one time at each station for each date sampled in the historical data. The reported latitude and longitude for the 2016 samples are the coordinates of the first replicate sample collected. Table $\mathrm{S}^{1}$ in the Supplementary data lists the coordinates for all replicate samples collected.

'Water depth was recorded only one time at each station for each date sampled in the historical data. Water depth was averaged for each station sampled in 2016 . Table S1 ${ }^{1}$ in the Supplementary data lists the water depth for all replicate samples collected. 
samples from 2016, which were also collected when the bay was free of sea ice (in October). All of the samples from 2016 were collected under Nunavut Research Institute (NRI) License No. 01029 16R-M. These samples were fixed in 10\% formalin for $24 \mathrm{~h}$ before being transferred to $70 \%$ ethanol for long-term preservation.

Sediment samples collected in 2016 were frozen and later analyzed for grain size, total organic carbon (TOC) content (\%), total nitrogen (TN) content (\%), and carbon:nitrogen ratio to compare with the historical samples. Grain size analysis was performed to determine the proportion of mud (silt and clay; $<0.063 \mathrm{~mm}$ ) and sand $(0.063-2.000 \mathrm{~mm})$ fractions in the sediment. Historical grain size analysis was performed using a hydrometer method (Wacasey et al. 1979, 1980), whereas the samples from 2016 were processed using the wet sieve method, where approximately $100 \mathrm{~g}$ of dried sediment was lightly rinsed through 0.063 and $2 \mathrm{~mm}$ sieves with water to break up the particles, then dried and weighed. The $>2.0 \mathrm{~mm}$ gravel fraction from the 2016 sediments was not examined because these data were not available historically, and no comparison of this size fraction could be made. The mass of each grain size fraction was divided by the total mass of the sample to determine the proportion of mud and sand in the sediments. Historically, TN and TOC were determined using the semi-micro Kjeldahl procedure and Walkley-Black procedure, respectively (Wacasey et al. 1979, 1980). In 2016, sediment samples were processed for TOC and TN in the Stable Isotope Lab at Memorial University, following the methods of Heiri et al. (2001) using a Carlo-Erba NA1500 Elemental Analyser and ConFLoIII interface (Supplementary data, Table S2 ${ }^{1}$ ). Between 13 and $15 \mathrm{mg}$ of sediment was used from each unhomogenized sediment sample to perform loss-on-ignition analysis to determine the percentage of organic carbon and nitrogen in the surface sediments. Triplicate samples were averaged for each station. Carbon:nitrogen ratios were computed from the TOC and TN data for both historical and modern samples to provide an indication of the source of organic matter in the sediments (i.e., terrestrial vs. marine).

A detailed sampling methodology for the collection of historical infaunal and sediment samples can be found in Wacasey et al. $(1979,1980)$. Differences in infaunal sample collection, including the use of different benthic grabs and the number of grabs collected at each station, during each sampling period, may have influenced the molluscan assemblages observed in their census. However, studies comparing different benthic grabs have indicated minimal differences between gear types when the total number of animals sampled are examined (Kutty and Desai 1968; Boyd et al. 2006; Holte and Buhl-Mortensen 2020). Similarly, the methodology for processing sediment samples (e.g., grain size, TOC, $\mathrm{TN}$, and carbon:nitrogen ratios) differed between time periods. There is no single preferred technique for grain size analysis, and most techniques have shown minor differences in results (Goossens 2008; Romano et al. 2017). The grain size data in this study are considered comparable, given the broad grain fractions (sand and mud) examined. The different methodologies employed for determining TOC and TN have both provided reliable results in other studies (e.g., Craft et al. 1991; Wang et al. 2013), thus the comparison of historical and modern sample results was also not expected to be influenced greatly by the different methodologies employed.

\section{Data analysis}

Species accumulation curves were generated for all of the historical and modern mollusc samples RStudio (R Studio Team 2020) to confirm whether sampling effort in this study satisfactorily represented mollusc diversity in inner Frobisher Bay. All of the models in this study (described below) were run using the aov function in RStudio (R Studio Team 2020) and ANOVA tables (Type III) were produced for each model using the 'car' package (Fox and Weisberg 2019) because historical and modern sample sizes in each region were 
unbalanced. A significance level of $\alpha=0.05$ was used for all of our statistical analyses, and marginally significant results were considered carefully. All of our models were tested for homogeneity of variance, independence, and normality to look for violations of model assumptions (Zuur et al. 2010). Homogeneity of regression line slopes (parallel lines) were also examined. Where model assumptions were not met, an interaction term was retained in the model. All of the models examined in this study are described below. Diversity indices and multivariate analyses were run using Primer v6 (Clarke and Warwick 2001).

\section{Long-term environmental datasets}

General linear models were developed in RStudio (R Studio Team 2020) to identify significant long-term changes that have occurred in the environment. The response variables temperature $\left({ }^{\circ} \mathrm{C}\right)$, length of ice season (days), maximum ice thickness (cm), average monthly water discharge, and the explanatory variable year were included in the models.

\section{Sediment composition and quality}

Stations sampled in the Iqaluit and Cairn Island regions were separated by a minimum of $4 \mathrm{~km}$. Preliminary data investigation indicated that the depth range of stations in each region were significantly different, and there were also significant differences in sediment characteristics and diversity indices between each region (Supplementary data, Table S3-A ${ }^{1}$ ). Therefore, models examining these indices were developed separately for each region so that within-region changes among diversity indices and sediment characteristics between the two time periods could be fully understood. Models were developed to determine whether the response variables - grain size, TOC, TN, and carbon:nitrogen ratio were significantly different between the two time periods for each region. The explanatory variables included in the models were time period (categories: historical and modern), water depth, and an interaction term (time period $\times$ depth). Water depth and the interaction term were included in the models because depth was not consistent at some stations between the two time periods, and because water depth varied among stations within each region and may have influenced the model results. For example, the water depth measured in 1973 at Iqaluit Station F3 was $30 \mathrm{~m}$, but in 2016, the water depth at this location was $11.5 \mathrm{~m}$. Similarly, the water depth measured in 1969 at Cairn Island Station F11 was $31 \mathrm{~m}$, and in 2016, water depth at this location was $77.2 \mathrm{~m}$ (Table 1). The five Iqaluit stations ranged in water depth from 8.5 to $43 \mathrm{~m}$, and the six Cairn Island stations ranged in water depth from 26 to $90 \mathrm{~m}$ (Table 1$)$.

\section{Diversity indices}

Diversity indices were generated for each historical and modern station, understanding that combining individual grabs together can result in a generalization of the mollusc composition at each station, and that this method does not necessarily reflect the composition of individual grabs. Similar to the sediment analysis, our models were developed to determine whether the response variables species richness $(S)$, Shannon-Weiner diversity $\left(\mathrm{H}^{\prime}\right)$, and Pielou's evenness $\left(J^{\prime}\right)$ were significantly different between the two time periods in each region. The explanatory variables time period (categories: historical and modern), water depth, and an interaction term (time period $\times$ depth) were also included in these models for similar reasons as described for the sediment analyses.

\section{Multivariate analysis}

Multivariate analysis was performed to examine differences in molluscan communities in the Iqaluit and Cairn Island regions between the two time periods. Bray-Curtis similarity matrices were generated from the square-root transformed abundance dataset because this transformation reduces the influence of highly abundant species and increases the 
influence of rare species (Clarke and Warwick 2001). Initial data exploration of a fourth root transformation returned a similar result as the square-root transformation; therefore, the less severe transformation was used. Rare species were not removed from the dataset because preliminary data exploration indicated that the natural groupings of stations were not influenced by their removal. One-way analysis of similarities (ANOSIM) was performed on the molluscan assemblages in inner Frobisher Bay to determine whether the Iqaluit and Cairn assemblages different between the two time periods. Four groups were examined in the analysis: (1) historical, Iqaluit; (2) modern, Iqaluit; (3) historical, Cairn Island; and (4) modern, Cairn Island. One-way ANOSIM was performed because we were only interested in comparing the historical and modern Iqaluit region and the historical and modern Cairn Island region, and we were not interested in comparing the Iqaluit region with the Cairn Island region (in space or time). A global $R$ value was generated, which provides a measure of significance for the dissimilarity between all four groups, whereas individual $R$ values provide a measure of significance for each assemblage combination with the comparison of historical and modern Iqaluit and historical and modern Cairn Island stations of interest in this study. Nonmetric multidimensional scaling (nMDS) was performed to visualize the similarities and differences between the four groups. Similarity percentage analysis (SIMPER) was performed on the square-root transformed dataset to identify species that were driving the similarity or dissimilarity between each of the groups of samples.

\section{Seasonal and interannual variability at select historical stations}

Seasonal and interannual variability was examined at stations F1, F2, F6, and F7 and compared the samples from 2016 collected at these stations, to determine the extent of shortterm variability versus long-term change. Visual inspection of species richness data for all repeated sampling events was undertaken and a nMDS plot was produced to evaluate the compositional difference observed in the 2016 samples compared with the historical samples for each of these four stations.

\section{Results}

Long-term environmental change

The mean annual air temperature in Iqaluit increased significantly over time between 1967 and $2017\left(F_{[1,49]}=8.966 ; p=0.0043\right.$; Fig. 3A). Between 1967 and 2016, the duration of the ice cover season decreased significantly $\left(F_{[1,35]}=64.33 ; p=1.94 \times 10^{-9}\right.$; Fig. 3B $)$. Thickness of the sea ice showed a weak declining trend over time $\left(F_{[1,41]}=3.488 ; p=0.069\right.$; Fig. 3 C). The average instantaneous river water discharge rate increased significantly over time during the month of June between 1971 and 2015 in the Sylvia Grinnell River $\left(F_{[1,18]}=13.36 ; p=0.00181\right.$; Fig. 3D). Similarly, average instantaneous river water discharge rates increased significantly over time during the month of June between 1982 and 2015 in the Apex River $\left(F_{[1,18]}=6.94 ; p=0.0168 ;\right.$ Fig. $\left.3 E\right)$. Instantaneous river discharge rates did not change significantly over time for either river between the months of July and September.

Grain size composition $\left(F_{[1,9]}=3.9478, p=0.078\right)$, TOC $\left(F_{[1,9]}=0.8094, p=0.392\right)$, and carbon:nitrogen ratio $\left(F_{[1,10]}=0.8528, p=0.378\right)$ did not change significantly in the Iqaluit region between the two time periods, but TN in the sediment was significantly lower in 2016 compared with the historical samples $\left(F_{[1,9]}=5.7325, p=0.040 ;\right.$ Fig. 4). Assumptions were met for all of the models except for the analysis of TN, where the homogeneity of regression slopes assumption was not met. As a result, both the covariate (water depth) and interaction term (time period $\times$ water depth) were retained in the model even though both returned a nonsignificant result, concluding that TN was not influenced by water depth or time period. Grain size composition $\left(F_{[1,11]}=0.0006, p=0.981\right)$ and carbon:nitrogen 
Fig. 3. Long-term air temperature, sea ice, and water discharge trends observed in Frobisher Bay. (A) significant increase in mean annual temperature from the city of Iqaluit between 1967 and 2017 (Government of Canada 2018a). (B) Significant decline in the duration of the ice cover season in Frobisher Bay near Iqaluit between 1967 and 2016 (Government of Canada 2017). (C) Nonsignificant declining trend in sea ice thickness in Frobisher Bay near Iqaluit between 1967 and 2016 (Government of Canada 2017). (D) Significant decline in average instantaneous discharge for the Sylvia Grinnell River during the month of June between 1971 and 2012 (Government of Canada 2018b). (E) Significant decline in average instantaneous discharge for the Apex River during the month of June between 1982 and 2015 (Government of Canada 2018b).
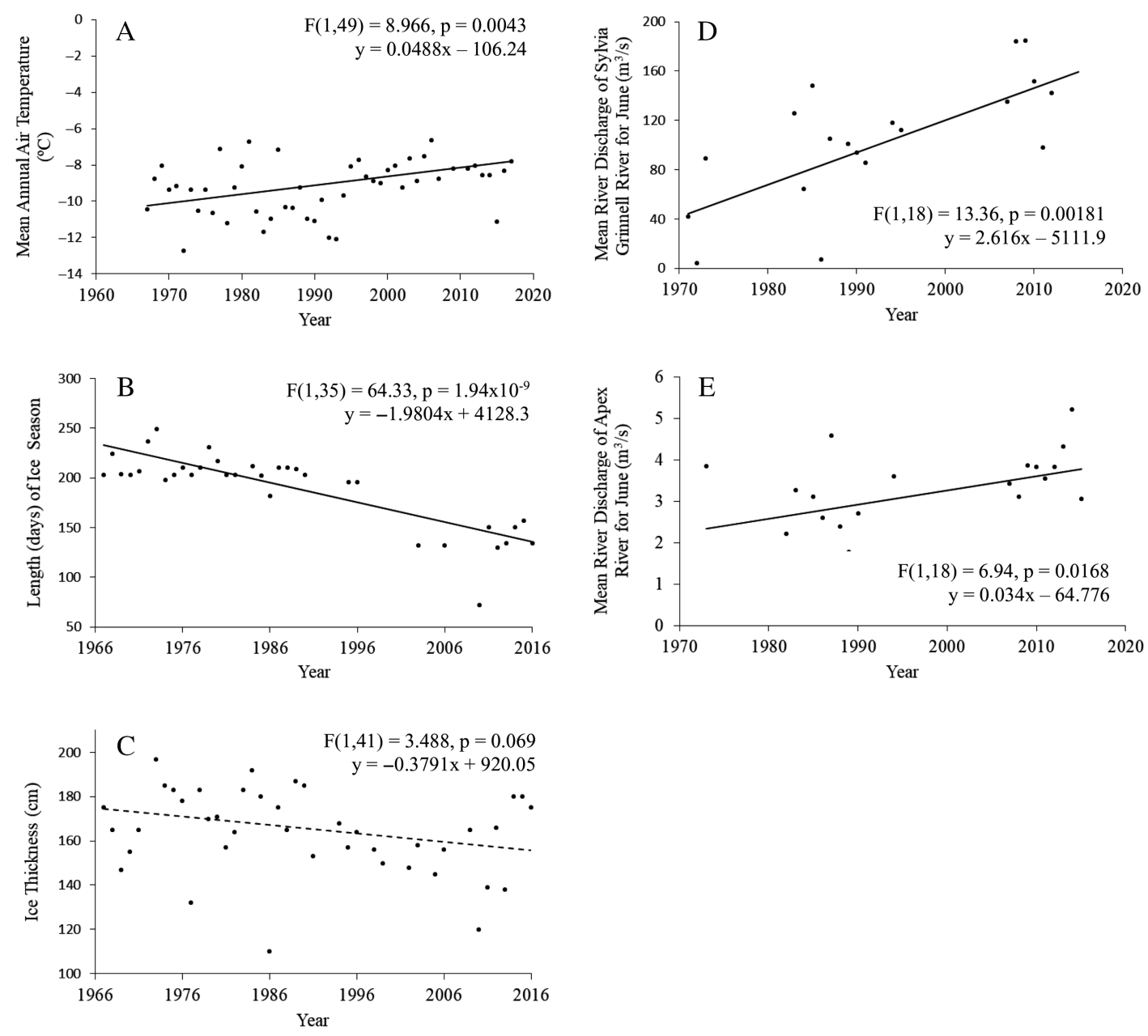

ratio $\left(F_{[1,8]}=0.0537, p=0.823\right)$ did not change significantly in the Cairn Island region between the two time periods, but TOC $\left(F_{[1,9]}=10.41, p=0.010\right)$ and $\operatorname{TN}\left(F_{[1,9]}=5.155\right.$, $p=0.0493$ ) did increase significantly in 2016 compared with 1967-1976 (Fig. 4). Water depth was retained as a covariate in these models, but the interaction term was not. Water depth did not affect TOC $\left(F_{[1,9]}=1.1818, p=0.305\right)$ between the two time periods but did affect TN $\left(F_{[1,9]}=6.88, p=0.0277\right)$.

In both regions, sediment grain size appears (visually) to have exhibited a change in composition in 2016 compared with the historical data (Fig. 4). However, inclusion of the interaction term (time period $\times$ water depth) in the model resulted in a nonsignificant result between the two time periods. These results were interpreted cautiously. 
Fig. 4. Mean (A) total organic carbon (TOC), (B) total nitrogen (TN), (C) carbon:nitrogen ratio, and (D and E) grain size (\% composition of silt and sand) compared between the historical and modern samples in the Iqaluit and Cairn Island regions of Frobisher Bay; ${ }^{*}, p<0.05$.
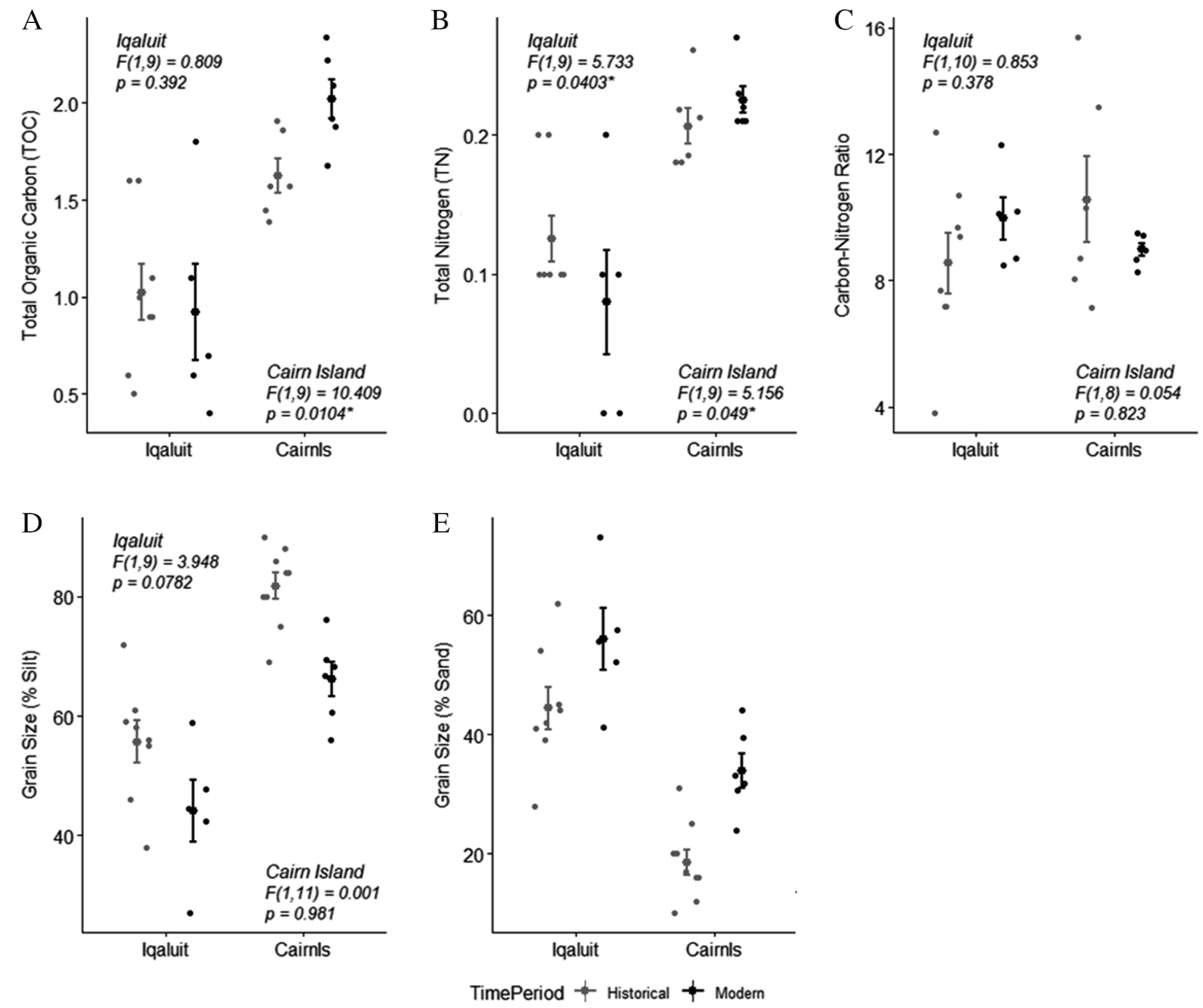

Table $S 3^{1}$ (parts B and D) in the Supplementary data includes all of the ANOVA results for the models described above.

\section{Molluscan diversity}

Sixty-four mollusc species were identified within the historical samples. Of these, $34.4 \%$ (22 species) were bivalves, and 65.6\% (42 species) were gastropods. The same stations were sampled again in 2016, and a total of 692 individuals were identified to the species level. Fifty-one mollusc species were identified within the modern samples, of which $47.1 \%$ (24 species) were bivalves, and 52.9\% (27 species) were gastropods. Most of the same bivalve species were observed in both the historical and modern samples, whereas some of the gastropod species were less common and appeared either only in the historical samples or only in the modern samples (Table 2). The most common molluscan taxa experienced a large decline in abundance in 2016 in the Iqaluit region, and a lesser decline in the Cairn Island region (Table 3). Species accumulation curves generated for the historical and modern pooled samples indicated some flattening of the curve, and the standard error observed 
Table 2. Bivalve and gastropod molluscs found in Iqaluit and Cairn Island samples in Frobisher Bay in 1967-1976 and 2016.

\begin{tabular}{|c|c|c|c|c|c|}
\hline Species & $1967-1976^{a}$ & 2016 & Species & $1967-1976^{a}$ & 2016 \\
\hline \multicolumn{6}{|l|}{ Gastropods } \\
\hline Admete viridula & $\mathrm{X}$ & $\mathrm{X}$ & Propebela turricula & $\mathrm{X}$ & $\mathrm{X}$ \\
\hline Alvania moerchi & $\mathrm{X}$ & $\mathrm{X}$ & Puncturella noachina & $\mathrm{X}$ & \\
\hline Anatoma crispata & $\mathrm{X}$ & $\mathrm{X}$ & Retusa obtusa & $\mathrm{X}$ & \\
\hline Anomalisipho verkruezeni & & $\mathrm{X}$ & Retusophiline lima & $\mathrm{X}$ & \\
\hline Ariadnaria borealis & $\mathrm{X}$ & $\mathrm{X}$ & Tachyrhynchus reticulatus & $\mathrm{X}$ & $\mathrm{X}$ \\
\hline Astyris rosacea & $\mathrm{X}$ & & Trichotropis bicarinata & $\mathrm{X}$ & \\
\hline Aulacofusus brevicauda & & $\mathrm{X}$ & Trichotropis conica & $\mathrm{X}$ & \\
\hline Boreotrophon clathratus & & $\mathrm{X}$ & Tritia lima & $\mathrm{X}$ & \\
\hline Buccinum hydrophanum & $\mathrm{X}$ & & Velutina velutina & $\mathrm{X}$ & \\
\hline Buccinum undatum & $\mathrm{X}$ & & Ziminella salmonacea & $\mathrm{X}$ & \\
\hline Cadlina laevis & $\mathrm{X}$ & & & & \\
\hline Colus holboelli & $\mathrm{X}$ & $\mathrm{X}$ & Bivalves & & \\
\hline Colus islandicus & & $\mathrm{X}$ & Astarte borealis & $\mathrm{X}$ & $\mathrm{X}$ \\
\hline Colus pubescens & $\mathrm{X}$ & $\mathrm{X}$ & Astarte montagui & $\mathrm{X}$ & $\mathrm{X}$ \\
\hline Colus sabini & & $\mathrm{X}$ & Axinopsida orbiculata & $\mathrm{X}$ & $\mathrm{X}$ \\
\hline Cryptonatica affinis & $\mathrm{X}$ & $\mathrm{X}$ & Ciliatocardium ciliatum & $\mathrm{X}$ & $\mathrm{X}$ \\
\hline Curtitoma decussata & & $\mathrm{X}$ & Crenella faba & & $\mathrm{X}$ \\
\hline Curtitoma incisula & $\mathrm{X}$ & & Dacrydium vitreum & $\mathrm{X}$ & $\mathrm{X}$ \\
\hline Curtitoma violacea & $\mathrm{X}$ & & Ennucula tenuis & $\mathrm{X}$ & $\mathrm{X}$ \\
\hline Curtitoma trevelliana & & $\mathrm{X}$ & Hiatella arctica & $\mathrm{X}$ & $\mathrm{X}$ \\
\hline Cylichna alba & $\mathrm{X}$ & $\mathrm{X}$ & Liocyma fluctuosa & $\mathrm{X}$ & $\mathrm{X}$ \\
\hline Cylichnoides occultus & $\mathrm{X}$ & $\mathrm{X}$ & Lyonsia arenosa & $\mathrm{X}$ & $\mathrm{X}$ \\
\hline Ecrobia truncata & $\mathrm{X}$ & & Macoma calcarea & $\mathrm{X}$ & $\mathrm{X}$ \\
\hline Erginus rubellus & $\mathrm{X}$ & & Macoma loveni & & $\mathrm{X}$ \\
\hline Euspira pallida & $\mathrm{X}$ & $\mathrm{X}$ & Macoma moesta & $\mathrm{X}$ & $\mathrm{X}$ \\
\hline Frigidoalvania cruenta & & $\mathrm{X}$ & Macoma torelli & $\mathrm{X}$ & $\mathrm{X}$ \\
\hline Lepeta caeca & $\mathrm{X}$ & $\mathrm{X}$ & Musculus discors & $\mathrm{X}$ & $\mathrm{X}$ \\
\hline Limneria undata & $\mathrm{X}$ & & Musculus niger & $\mathrm{X}$ & $\mathrm{X}$ \\
\hline Margarites costalis & $\mathrm{X}$ & $\mathrm{X}$ & Mya truncata & $\mathrm{X}$ & $\mathrm{X}$ \\
\hline Margarites groenlandicus & $\mathrm{X}$ & $\mathrm{X}$ & Nuculana minuta & $\mathrm{X}$ & $\mathrm{X}$ \\
\hline Margarites groenlandicus umbilicalis & $\mathrm{X}$ & $\mathrm{X}$ & Nuculana pernula & $\mathrm{X}$ & $\mathrm{X}$ \\
\hline Margarites helicinus & $\mathrm{X}$ & $\mathrm{X}$ & Pandora glacialis & $\mathrm{X}$ & \\
\hline Margarites olivaceus & $\mathrm{X}$ & $\mathrm{X}$ & Parathyasira dunbari & & $\mathrm{X}$ \\
\hline Margarites vahli & $\mathrm{X}$ & & Parvicardium pinnulatum & & $\mathrm{X}$ \\
\hline Moelleria costulata & $\mathrm{X}$ & $\mathrm{X}$ & Periploma aleuticum & $\mathrm{X}$ & \\
\hline Nepotilla amoena & $\mathrm{X}$ & & Portlandia arctica & & $\mathrm{X}$ \\
\hline Neptunea despecta & $\mathrm{X}$ & & Serripes groenlandicus & $\mathrm{X}$ & $\mathrm{X}$ \\
\hline Onoba mighelsii & $\mathrm{X}$ & & Similipecten greenlandicus & $\mathrm{X}$ & \\
\hline Oenopota declivis & $\mathrm{X}$ & $\mathrm{X}$ & Thracia myopsis & & $\mathrm{X}$ \\
\hline Oenopota pyramidalis & $\mathrm{X}$ & $\mathrm{X}$ & Thyasira gouldi & $\mathrm{X}$ & $\mathrm{X}$ \\
\hline Praephiline finmarchica & $\mathrm{X}$ & & Yoldia hyperborea & $\mathrm{X}$ & $\mathrm{X}$ \\
\hline Propebela arctica & $\mathrm{X}$ & & Yoldiella lenticula & & $\mathrm{X}$ \\
\hline
\end{tabular}

Note: Species names have been checked and are consistent with WoRMS (2021).

for both the historical and modern samples overlap for the first 10 samples examined (Appendix A, Fig. A1).

Stations F1-F5 sampled in the Iqaluit region were located in relatively shallow water $(8.5-43.0 \mathrm{~m})$. Species richness ranged between 3 and 22 species, and species diversity and evenness were low at most stations sampled in this region (Fig. 5). Within the Iqaluit region, station F4 exhibited the greatest species diversity and the smallest amount of change in species richness over time, while station F3 experienced the greatest change in species richness over time, with a loss of 16 species at this station. The most common molluscs in the historical Iqaluit samples included the bivalves Axinopsida orbiculata, Ennucula tenuis, and Thyasira gouldi, and the gastropods Cylichna alba and Retusa obtusa, and the most common molluscs in the modern Iqaluit samples included the bivalves A. orbiculata, E. tenuis, and 
Table 3. Abundance $\left(n / \mathrm{m}^{2}\right)$ of the most common taxa observed in historical and modern samples for the Iqaluit and Cairn Island regions (in bold font).

\begin{tabular}{lllll}
\hline Species & $\begin{array}{l}\text { Historical } \\
\text { Cairn Is. }\left(n / \mathrm{m}^{2}\right)\end{array}$ & $\begin{array}{l}\text { Modern } \\
\text { Cairn Is. }\left(\mathrm{n} / \mathrm{m}^{2}\right)\end{array}$ & $\begin{array}{l}\text { Historical } \\
\text { Iqaluit }\left(n / \mathrm{m}^{2}\right)\end{array}$ & $\begin{array}{l}\text { Modern } \\
\text { Iqaluit }\left(n / \mathrm{m}^{2}\right)\end{array}$ \\
\hline Axinopsida orbiculata & & & $\mathbf{6 8 5 . 6}$ & 87.7 \\
Ennucula tenuis & $\mathbf{3 5 . 0}$ & $\mathbf{2 0 . 1}$ & $\mathbf{8 7 . 3}$ & $\mathbf{1 7 . 2}$ \\
Hiatella arctica & $\mathbf{2 6 . 3}$ & $\mathbf{9 . 2}$ & & \\
Macoma moesta & 4.2 & $\mathbf{1 1 . 0}$ & & \\
Musculus discors & $\mathbf{4 0 . 7}$ & 16.1 & & \\
Nuculana minuta & $\mathbf{1 9 . 5}$ & 5.0 & & \\
Nuculana pernula & 3.1 & $\mathbf{1 3 . 1}$ & $\mathbf{2 6 0 . 2}$ & 109.1 \\
Thyasira gouldi & $\mathbf{7 8 . 4}$ & $\mathbf{7 4 . 8}$ & & \\
Yoldia hyperborea & 0.0 & $\mathbf{8 . 1}$ & $\mathbf{1 1 9 . 1}$ & 8.0 \\
Cylichna alba & $\mathbf{7 . 3}$ & $\mathbf{9 . 5}$ & $\mathbf{9 2 . 4}$ & 0.0 \\
Retusa obtusa & & &
\end{tabular}

Note: The values not in bold font are presented for comparison. Taxa were considered common if they were present in all of, or all but one of, the samples collected in each region during each time period (e.g., present in at least 8 out of 9 historical Iqaluit samples, 4 out of 5 modern Iqaluit samples, 10 out of 11 historical Cairn Island samples, 7 out of 8 modern Cairn Island samples). Historical data were compiled from Wacasey et al. $(1979,1980)$.

Fig. 5. Mean (A) species richness $(S)$, (B) Shannon-Weiner diversity $\left(H^{\prime}\right)$, and $(C)$ Pileou's evenness $\left(J^{\prime}\right)$ with standard error for historical and modern samples collected in Frobisher Bay. Each points represents a pooled sample collected in each region during each time period.
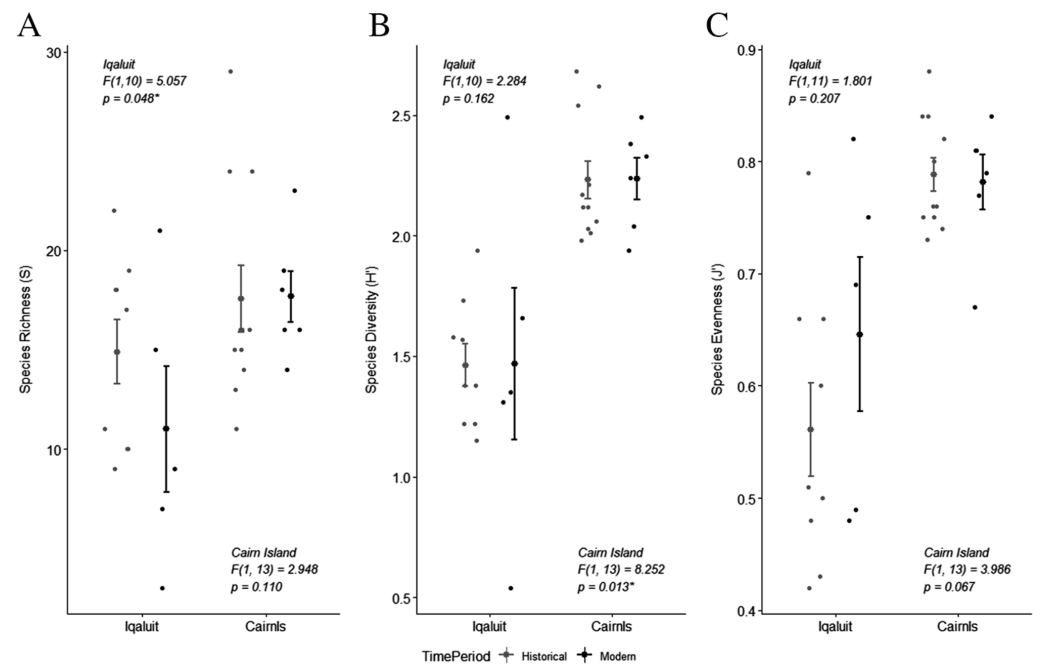

T. gouldi, although these three species were not found in all of the samples collected. Axinopsida orbiculata decreased from 686 to only 88 individuals $/ \mathrm{m}^{2} ;$ T. gouldi decreased from 260 to 109 individuals $/ \mathrm{m}^{2}$; and C. alba declined from 119 to 8 individuals $/ \mathrm{m}^{2}$ (Table 3).

Stations F6-F11 sampled in the Cairn Island region were located in deeper water, ranging between 26.0 and $90.1 \mathrm{~m}$. Species richness was higher overall at these stations (between 11 and 29 species) compared with the Iqaluit stations. Species diversity and evenness were also consistently higher at these stations (Fig. 5). Station F11 exhibited the greatest decline in species richness between the two time periods, whereas all of the other Cairn Island stations exhibited gains or losses of only a few species. The most common molluscs in the historical Cairn Island samples included the bivalves E. tenuis, Hiatella arctica, Musculus discors, Nuculana minuta, T. gouldi, and the gastropod C. alba. The most common molluscs in 
the modern Cairn Island samples included the bivalves E. tenuis, H. arctica, Macoma moesta, Nuculana pernula, T. gouldi, Yoldia hyperborea, and the gastropod C. alba. Half of the most abundant taxa in the Cairn Island region experienced a decline in abundance in 2016, but this change was less noticeable compared with the Iqaluit region. Thyasira gouldi exhibited a decline in abundance of only 3 individuals $/ \mathrm{m}^{2}$. Musculus discors decreased in abundance from 41 to 16 individuals $/ \mathrm{m}^{2}$, and E. tenuis declined from 35 to 20 individuals $/ \mathrm{m}^{2}$ (Table 3).

Species richness declined significantly between the two time periods in the Iqaluit region $\left(F_{[1,10]}=5.0567, p=0.0829\right)$ but did not change significantly in the Cairn Island region $\left(F_{[1,13]}=2.9476, p=0.1097\right)$ where water depth influenced species richness (Fig. 5$)$. There was no significant change in species diversity between the time periods in the Iqaluit region $\left(F_{[1,10]}=2.2843, p=0.1616\right)$, but there was a significant increase in the Cairn Island region $\left(F_{[1,13]}=8.2524, p=0.0131\right)$. Here, species diversity changed significantly with water depth $\left(F_{[1,13]}=7.6132, p=0.0163\right)$ and with time $\left(F_{[1,13]}=9.7543, p=0.0081\right.$; Fig. 5$)$. Species evenness did not change significantly between time periods in the Iqaluit region $\left(F_{[1,11]}=1.8010\right.$, $p=0.207)$ or the Cairn Island region $\left(F_{[1,13]}=3.9862, p=0.06727\right.$; Fig. 5$)$. The Table $S 3^{1}$ (parts E and F) in the Supplementary data includes all of the ANOVA results for the models described herein.

\section{Multivariate analysis}

The historical molluscan assemblages in the Iqaluit and Cairn Island regions differed significantly from the modern mollusc assemblages in these regions, as confirmed through multivariate analyses (global $R=0.683, p<0.001$, ANOSIM; Fig. 6). The historical Iqaluit samples were significantly different from the modern Iqaluit samples (global $R=0.627$, $p<0.001$, ANOSIM), and the historical Cairn Island samples were significantly different from modern Cairn Island samples (global $R=0.637, p<0.001$, ANOSIM).

SIMPER analysis confirmed that the historical Iqaluit stations were similar to each other (by $52.3 \%$ ), whereas the modern Iqaluit stations were only $24.6 \%$ similar to each other. In both time periods, A. orbiculata contributed the most significantly to within-station similarity (Table 4). The historical Iqaluit stations clustered together, whereas the modern Iqaluit stations were more dispersed in the nMDS plot (Fig. 6). The historical and modern Iqaluit samples were $72.86 \%$ dissimilar (Table 4). The thyasirid bivalves A. orbiculata and T. gouldi contributed most significantly to the dissimilarity observed over time, potentially the result of a steep decline in relative abundance of these species in the modern samples compared with the historical samples. Cylichna alba, R. obtusa, and E. tenuis also contributed to over $50 \%$ of the dissimilarity between the historical and modern Iqaluit samples (Table 5).

The Cairn Island region did not exhibit as dramatic a change in molluscan composition between the two time periods compared with the Iqaluit region. SIMPER analyses confirmed that the historical Cairn Island station samples were $54.0 \%$ similar to each other, whereas the samples from the modern Cairn Island stations were 53.1\% similar to each other. In both time periods, the thyasirid bivalve T. gouldi contributed most significantly to within-station similarity (Table 4). Both the historical and modern Cairn Island samples clustered more closely together in the nMDS plot (Fig. 6) compared with the Iqaluit samples. The historical and modern Cairn Island samples were 59.9\% dissimilar, and there were many more species that contributed to the dissimilarity observed. The top five species that contributed to the dissimilarity between time periods in the Cairn Island region only contributed $23.4 \%$ of the dissimilarity observed, whereas in the Iqaluit region, the top five species contributed $52.5 \%$ of the temporal dissimilarity (Table 5). 
Fig. 6. Nonmetric multidimensional scaling plot of the benthic community in Frobisher Bay sampled in the Iqaluit and Cairn Island regions between 1967 and 1976 (historical) and in 2016 (modern). Results are based on square-root transformed data, and these communities were deemed significantly different from each other through one-way ANOSIM (global $R=0.683$, all pairwise comparisons produced $p<0.05$ ).

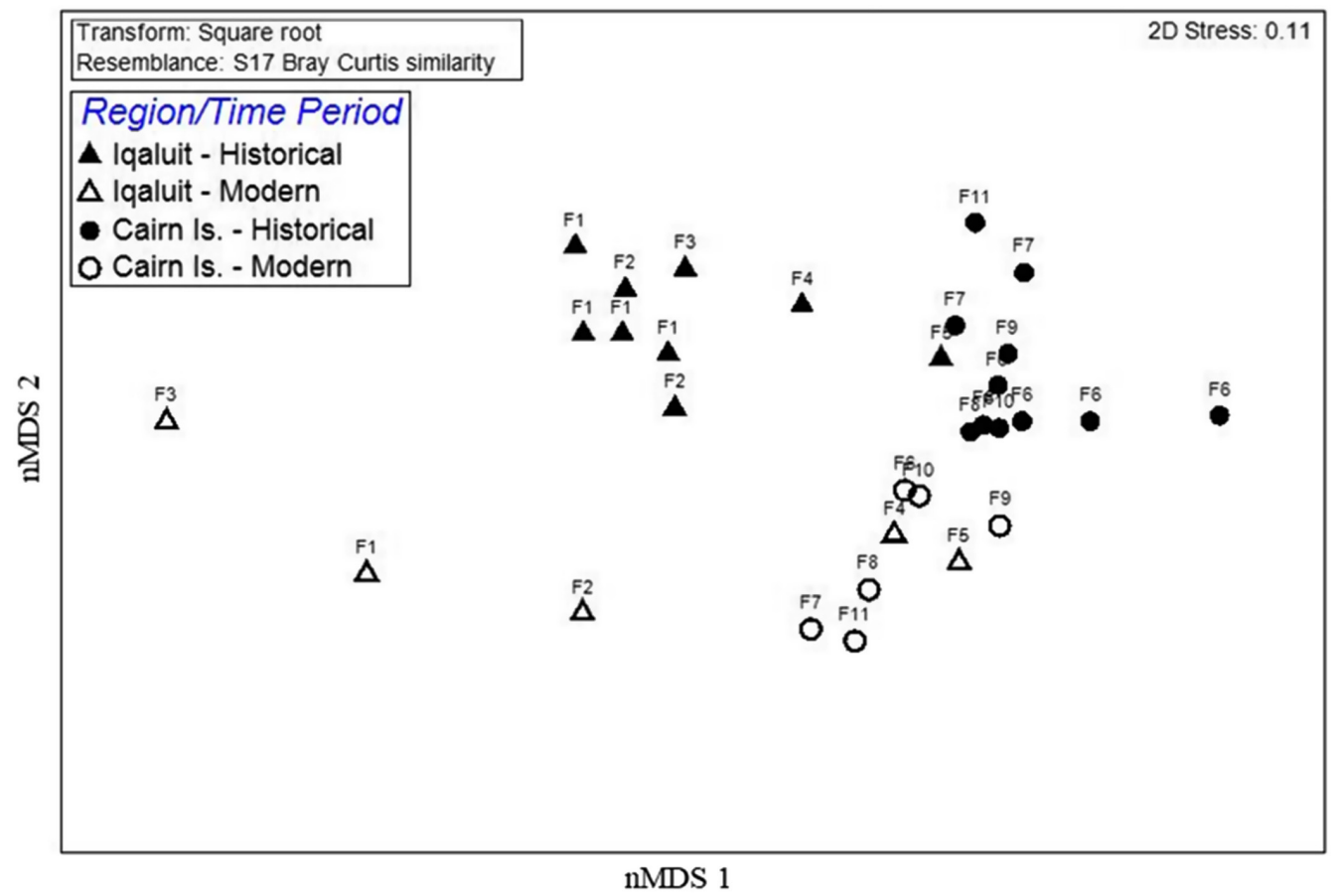

Short-term and interannual change

Station F1 was sampled five times between 1969 and 1976. Species richness at this station increased from 10 to 17 species between July and September 1969; in August 1973, species richness declined to 10 species, and in August 1976, species richness had increased to 18 species. When re-sampled in 2016, species richness had declined to 7 species. Station F2 was sampled in 1973 and again in 1976 and exhibited a 100\% increase in species richness, from 9 to 18 species. In 2016, a 100\% change in species richness was observed, with a decline to 9 species observed at this station. Station F6 was sampled four times between July and October 1968 and again in 1970. Species richness ranged between 11 and 16 species in the 1968 samples, species richness increased to 14 species in 1970, and in 2016, species richness increased further to 24 species. Lastly, station F7 was sampled on 1 August 1968 and 20 August 1968, and species richness increased from 16 to 24 species during this short time period. In 2016, species richness had declined to 16 species (Table 6). An nMDS plot of this square-root transformed community data demonstrates the high seasonal and interannual variability between the historical sampling events and the modern samples collected for each of these stations (Fig. 7). The samples from 2016 collected at stations F1, F2, and F7 plot further from their respective historical stations cluster, whereas the sample from 2016 collected at station F6 plots roughly within the historical stations cluster. Further investigation into the compositional differences between the historical and modern assemblages at these four stations could not be examined through SIMPER analysis due to limited sample size from 2016. However, visual inspection of the assemblage data for stations F1 and F2 revealed that the biggest contributors to differences observed between the historical and modern stations in the Iqaluit region were a loss of the thyasird bivalves A. orbiculata and 
Table 4. Summary of SIMPER analysis identifying within-station similarity among the historical and modern Iqaluit and Cairn Island stations.

\begin{tabular}{|c|c|c|c|c|c|c|c|c|}
\hline \multirow[b]{2}{*}{ Region } & \multicolumn{4}{|c|}{ Historical samples } & \multicolumn{4}{|c|}{ Modern samples } \\
\hline & $\begin{array}{l}\text { Within-station } \\
\text { similarity (\%) }\end{array}$ & Species & $\begin{array}{l}\text { Contribution to } \\
\text { within-station } \\
\text { similarity (\%) }\end{array}$ & $\begin{array}{l}\text { Cumulative } \\
\text { contribution to } \\
\text { within-station } \\
\text { similarity (\%) }\end{array}$ & $\begin{array}{l}\text { Within- } \\
\text { station } \\
\text { similarity (\%) }\end{array}$ & Species & $\begin{array}{l}\text { Contribution to } \\
\text { within-station } \\
\text { similarity (\%) }\end{array}$ & $\begin{array}{l}\text { Cumulative } \\
\text { contribution to } \\
\text { within-station } \\
\text { similarity (\%) }\end{array}$ \\
\hline \multirow[t]{9}{*}{ Iqaluit } & 52.3 & Axinopsida orbiculata & 24.85 & 24.85 & 24.6 & Axinopsida orbiculata & 34.26 & 34.26 \\
\hline & & Thyasira gouldi & 19.37 & 44.22 & & Ennucula tenuis & 18.75 & 53.01 \\
\hline & & Cylichna alba & 15.61 & 59.83 & & Macoma moesta & 8.68 & 61.69 \\
\hline & & Ennucula tenuis & 12.07 & 71.9 & & Macoma calcarea & 7.05 & 68.74 \\
\hline & & Retusa obtusa & 11.13 & 83.03 & & Cylichna alba & 6.61 & 75.35 \\
\hline & & Retusophiline lima & 3.91 & 86.94 & & Thyasira gouldi & 6.2 & 81.55 \\
\hline & & Astarte borealis & 3.04 & 89.99 & & Thracia myopsis & 4.94 & 86.49 \\
\hline & & Macoma calcarea & 2.4 & 92.38 & & Hiatella arctica & 2.77 & 89.27 \\
\hline & & & & & & Yoldia hyperborea & 2.11 & 91.37 \\
\hline \multirow[t]{13}{*}{ Cairn Island } & 54.0 & Thyasira gouldi & 24.43 & 24.43 & 53.1 & Thyasira gouldi & 28.88 & 28.88 \\
\hline & & Musculus discors & 13.84 & 38.28 & & Enпucula tenuis & 14.25 & 43.13 \\
\hline & & Ennucula tenuis & 11.5 & 49.78 & & Nuculana pernula & 8.94 & 52.07 \\
\hline & & Nuculana minuta & 11.4 & 61.18 & & Cylichna alba & 8.77 & 60.84 \\
\hline & & & & & & Yoldia hyperborea & 5.75 & 66.58 \\
\hline & & Hiatella arctica & 8.97 & 70.15 & & Macoma moesta & 5.22 & 71.8 \\
\hline & & Dacrydium vitreum & 5.99 & 76.13 & & Hiatella arctica & 4.55 & 76.36 \\
\hline & & Cylichna alba & 5.09 & 81.22 & & Margarites helicinus & 3.89 & 80.25 \\
\hline & & Margarites olivaceus & 3.89 & 85.11 & & Frigidoalvania cruenta & 3.48 & 83.72 \\
\hline & & Mya truncata & 1.97 & 87.08 & & Musculus niger & 2.54 & 86.26 \\
\hline & & Musculus niger & 1.57 & 88.65 & & Macoma loveni & 1.7 & 87.97 \\
\hline & & Lepeta caeca & 1.52 & 90.17 & & Musculus discors & 1.48 & 89.45 \\
\hline & & & & & & Yoldiella lenticula & 1.43 & 90.88 \\
\hline
\end{tabular}


Table 5. Summary of SIMPER analysis identifying top five species that contributed to the dissimilarity between the historical and modern Iqaluit and Cairn Island stations.

\begin{tabular}{lllll}
\hline & $\begin{array}{l}\text { Dissimilarity } \\
\text { between historical } \\
\text { and modern } \\
\text { Region }\end{array}$ & $\begin{array}{l}\text { Species contributing } \\
\text { to dissimilarity }\end{array}$ & $\begin{array}{l}\text { Contribution to } \\
\text { dissimilarity (\%) }\end{array}$ & $\begin{array}{l}\text { Cumulative contribution } \\
\text { to dissimilarity (\%) }\end{array}$ \\
\hline Iqaluit & 72.86 & $\begin{array}{l}\text { Axinopsida orbiculata } \\
\text { Thyasira gouldi }\end{array}$ & 17.41 & 17.41 \\
& & Cylichna alba & 9.12 & 29.6 \\
& & Retusa obtusa & 8.69 & 38.72 \\
& & Ennucula tenuis & 5.1 & 47.42 \\
Cairn Island & \multirow{2}{*}{59.9} & Musculus discors & 6.38 & 52.51 \\
& & Nuculana minuta & 4.68 & 6.38 \\
& & Dacrydium vitreum & 4.19 & 11.07 \\
& & Nuculana pernula & 4.14 & 15.26 \\
& & Hiatella arctica & 4.04 & 19.4 \\
\hline
\end{tabular}

Table 6. Diversity indices for historical stations that were repeatedly sampled on a seasonal or interannual time scale between 1967 and 1976.

\begin{tabular}{llllll}
\hline Station & Region & Date & $\begin{array}{l}\text { Species } \\
\text { richness }(S)\end{array}$ & $\begin{array}{l}\text { Species } \\
\text { diversity }\left(H^{\prime}\right)\end{array}$ & $\begin{array}{l}\text { Species } \\
\text { evenness }\left(J^{\prime}\right)\end{array}$ \\
\hline F1(5b) & Iqaluit & 29-Jul-69 & 10 & 1.38 & 0.6 \\
F1(5b) & & 3-Sep-69 & 17 & 1.22 & 0.43 \\
F1(5b) & & 8-Aug-73 & 10 & 1.15 & 0.5 \\
F1(5b) & & 19-Aug-76 & 18 & 1.22 & 0.42 \\
F1 & & 10-Oct-16 & 7 & 1.35 & 0.69 \\
F2(25) & Iqaluit & 8-Aug-73 & 9 & 1.73 & 0.79 \\
F2(25) & & 18-Aug-76 & 18 & 1.38 & 0.48 \\
F2 & & 10-Oct-16 & 9 & 1.66 & 0.75 \\
F6(5) & Cairn Island & 23-Jul-68 & 16 & 2.21 & 0.8 \\
F6(5) & & 20-Aug-68 & 15 & 2.03 & 0.75 \\
F6(5) & & 3-Sep-68 & 13 & 2.17 & 0.84 \\
F6(5) & & 8-Oct-68 & 11 & 2.12 & 0.88 \\
F6(5) & & 6-Aug-70 & 14 & 2.01 & 0.76 \\
F6 & & 14-Oct-16 & 23 & 2.49 & 0.79 \\
F7(5a) & Cairn Island & 1-Aug-68 & 16 & 2.06 & 0.74 \\
F7(5a) & & 20-Aug-68 & 24 & 2.68 & 0.84 \\
F7 & & 14-Oct-16 & 16 & 2.33 & 0.84 \\
\hline
\end{tabular}

Note: Diversity indices for 2016 are also included to compare with the variability among historical samples.

T. gouldi and the gastropods C. alba and R. obtusa in the samples from 2016 from these stations. In the Cairn Island region, the changes were more subtle at stations F6 and F7, with numerous species exhibiting small differences in abundance between sampling events. Station F6 did exhibit a large increase in T. gouldi in 2016, and station F7 experienced a large decline in T. gouldi in 2016 in the Cairn Island region.

\section{Discussion}

Frobisher Bay experienced a significant long-term increase in mean annual air temperature, a significant loss of sea ice (confirmed through a shortened ice season), and a significant change in the hydrodynamics of the Sylvia Grinnell River and the Apex River during the month of June. Neither the Iqaluit region nor the Cairn Island region experienced a 
Fig. 7. nMDS plot (square-root transformed) showing seasonal and interannual variability of historical molluscan assemblages in relation to 2016 assemblages at four Frobisher Bay stations sampled repetitively between 1967 and 1976.

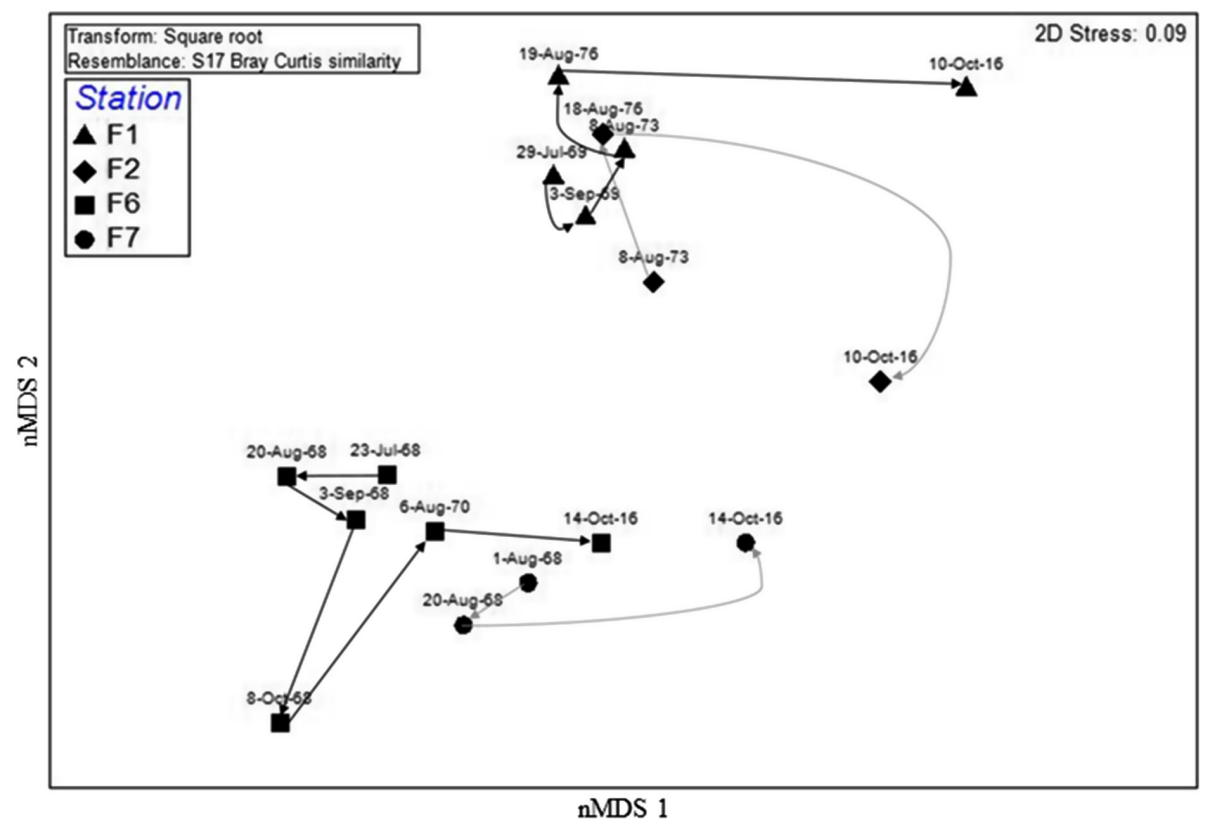

significant change in sediment grain size composition between the two time periods examined. The Iqaluit region experienced a significant decrease in TN in the sediments between the two time periods, whereas the Cairn Island region experienced a significant increase in TOC and TN in the sediments between the two time periods. However, carbon:nitrogen ratios did not change significantly between the two time periods in either region.

The mollusc assemblages in 2016 exhibited differences in composition compared with the historical mollusc assemblages observed 50 years earlier by Wacasey et al. $(1979,1980)$. The abundance of molluscs in the 2016 samples was lower in both the Iqaluit and Cairn Island regions compared with the historical data. The Iqaluit region exhibited the greatest change in composition, primarily due to the decline or complete loss of a few previously abundant species, including A. orbiculata and T. gouldi. Comparatively, molluscan assemblage change observed in the Cairn Island region was due to a larger number of mollusc species that exhibited smaller changes in abundance between the two time periods.

This study was limited to examining two "snap-shots" in time because consistent systematic benthic infaunal sampling did not take place between 1967 and 2016 in Frobisher Bay. Applying an appropriate time-scale to identify temporal variability is particularly important in measuring long-term change (Beuchel et al. 2006; Renaud et al. 2007; Kedra et al. 2010) as benthic communities are influenced by disturbance on a variety of time scales (seasonal to multidecadal; Beuchel and Gulliksen 2008). These various scales of disturbance can make distinguishing between long-term change and short-term variability difficult; the recommendations are that benthic community change should be measured at decadal scales (Renaud et al. 2007). The limitations of this study reflected in a $\sim 50$ year sampling gap are acknowledged.

Three important factors may have influenced the results observed in this study. First, there was spatial discrepancy in sampling between the two time periods. This is not an 
uncommon issue when utilizing historical datasets. For example, Renaud et al. (2007) experienced this same dilemma with the pooled historical dataset used in their multidecadal study examining the benthic community structure in an Arctic fjord in Svalbard, Norway. In this study, the historical positional data did not match the map provided in the data reports by Wacasey et al. $(1979,1980)$. This problem was overcome by georeferenceing the historical maps to obtain the coordinates that were used to collect the 2016 samples; however, there remained some evidence of spatial sampling inaccuracy because dissimilar water depths were observed at some individual stations between the two time periods (Table 1). This concern was minimized by grouping stations into two general areas: the "Iqaluit" and "Cairn Island" regions. Grouping individual stations into these two regions also addressed the concern over not being able to compare individual stations, owing to the small sample sizes from individual stations. A second concern related to water depth was that the stations sampled in the Iqaluit and Cairn Island regions each covered a broad range of water depths (Iqaluit: 11.5-43.0 m; Cairn Island: 26-73 m). Brown et al. (2011) observed differences in community structure at stations shallower than $10 \mathrm{~m}$ compared with stations deeper than $10 \mathrm{~m}$ in Gjoa Haven, King William Island, in the Canadian Arctic. To address the potential influence of water depth on the sediment and biological analysis for each region between the two time periods, water depth was included as a covariate in all of our models, and an interaction term (time period $\sim$ water depth) was also included in the models to test whether water depth and time period had an influence on the response variable being examined. Lastly, the molluscan assemblages may have been influenced by differences in the number of grabs that were combined to make up a sample. The larger number of grabs collected in the historical samples could have resulted in a greater diversity of species being collected if the bottom was patchy. Misiuk et al. (2019) described inner Frobisher Bay as having a heterogeneous seabed in their study mapping seabed sediments; however, patchiness of molluscan species among replicate samples was not examined in this study.

\section{Long-term change in the physical environment}

Benthic community composition is well known to be tightly linked to pelagic processes in the Arctic (Stasko et al. 2018). The loss of arctic sea ice can directly affect the benthos through increased light availability, which promotes phytoplankton blooms and increased organic sedimentation to the benthos (Clark et al. 2017). Frobisher Bay experienced a significant long-term reduction in the length of the ice cover season (Fig. 3), likely the result of a significant long-term increase in air temperatures in the region. Overeem et al. (2011) observed a similar trend along the Beaufort Sea coastline, which included the extension of the open water season from 45 to 95 days over a 50 year period. As more light becomes available, the quality and quantity of food resources available to the benthos changes (Hsiao 1992). Benthic fauna receive most of their nutrition from the deposition of ice algae when sea ice is present, but from phytoplankton in the water column when the sea ice has disappeared (Hsiao 1992; McMahon et al. 2006; Clark et al. 2017). A change in food resources available to the benthos can result in changes to the structure and function of the benthic community (McMahon et al. 2006). In regions covered by sea ice, the summer phytoplankton bloom is a major contributor of organic matter to the benthos (Clark et al. 2017). For example, Kedra et al. (2010) observed a greater amount of particulate organic carbon in the sediments of Kongsfjorden, Svalbard, as a result of increased primary production in the water column due to warming water temperatures. In Frobisher Bay, carbon:nitrogen ratios increased at 8 of 11 stations in the Iqaluit and Cairn Island regions between the two time periods (Appendix A, Fig. A2), suggesting that an increase in primary production in the water column may have also occurred here. However, no significant change in carbon: 
nitrogen ratio was observed at the region level (Iqaluit or Cairn Island) between the time periods. Furthermore, while historical phytoplankton data were collected in Frobisher Bay in 1976 and 1979-1981 (Hsiao and Pinkewycz 1983, 1985), no recent phytoplankton records were available to compare with the historical records to confirm whether a change in the timing or quantity and quality of the phytoplankton bloom had occurred in Frobisher Bay.

A change to the nival freshet (i.e., a significant increase in river discharge) in both the Sylvia Grinnell and Apex Rivers may have increased sediment delivery (clastic and organic) to the nearshore environments in Koojesse Inlet. River-water discharge affects water column stratification, nutrient cycling, primary production, and inorganic sedimentation, and these factors influence food supply to the benthos. Increased water turbidity reduces light penetration, which limits primary production and large inorganic sediment fluxes dilute organic matter delivered to the seabed (Atkinson and Wacasey 1987; Gorlich et al. 1987; Thrush et al. 2004; Wlodarska-Kowalczuk et al. 2005; Wassmann and Reigstad 2011). The Sylvia Grinnell and Apex rivers both demonstrated a significant increase in average instantaneous discharge rate during the month of June (the annual peak flow), suggesting that the timing of freshwater discharge from these rivers has changed over time. The proximity of these rivers to the study region suggest that they may have influenced the sedimentary and biotic characteristics of the local benthos. The model results for sediment compositional changes for both regions and time periods were interpreted cautiously. The proportion of silt in the samples from both regions appeared to be lower in the 2016 samples compared with the historical samples, whereas the proportion of sand in the samples from both regions appeared to be higher in the 2016 samples compared with the historical samples, although the differences were not statistically significant at $p<0.05$. Carbon:nitrogen ratios indicated that the source of carbon was marine and not terrestrial. Carbon:nitrogen ratios between 4 and 10 are indicative of marine-derived organic matter because phytoplankton and zooplankton characteristically have carbon:nitrogen ratios in this range (Rumolo et al. 2011). In comparison, terrestrial plants exhibit carbon:nitrogen ratios $>15$, and are indicative of a terrestrial source of carbon and nitrogen (Rumolo et al. 2011). One historical Iqaluit station (station F1) and four modern Iqaluit stations (F1, F3, F4, and F5) that were located closest to the Sylvia Grinnell River exhibited carbon:nitrogen ratio values $>10$, suggesting that the carbon sources may not be marine in this region. However, neither the Iqaluit nor the Cairn Island region experienced a significant change in carbon:nitrogen ratio between the two time periods, and no station in either time period exhibited carbon:nitrogen ratios $>15$ (Appendix A, Fig. A2), indicating that an overall increase in terrestrial input of organic matter to the benthos over time did not occur. By contrast, sediment cores collected from Koojesse Inlet, close to the locations of our Iqaluit stations, recorded anoxic sediment accumulation, which was interpreted as a signal of eutrophication coming from Iqaluit, most likely the Iqaluit offshore sewage disposal (Tremblay et al. 2020).

\section{Long-term benthic community change}

The molluscan assemblages in both the Iqaluit and Cairn Island regions were very different from each other in 2016 compared with 1967-1976. In the Iqaluit region, these changes can be attributed to a large decline in abundance of the most common taxa: A. orbiculata, T. gouldi, C. alba, R. obtusa, and E. tenuis (Table 3), which all contributed to over $50 \%$ of the dissimilarity observed between the two time periods (Table 5). Axinopsida orbiculata and T. gouldi cope well with sedimentation, are both typically found in organically enriched sediments across the Arctic (Batstone et al. 2014; Wlodarska-Kowalczuk 2007; Kedra et al. 2010; S. Dufour, personal communication), and are both listed as species that are tolerant of 
organic enrichment (WoRMS 2021). Thyasirid bivalves are mobile deposit feeders (Wlodarska-Kowalczuk 2007) that inhabit surface layers of the sediment; they can move in unstable, rapidly deposited sediments (Ockelmann 1958), and occur abundantly in areas such as in glacial bays (Wlodarska-Kowalczuk 2007). Species that are tolerant of disturbance thrive where there is excess organic enrichment (Borja et al. 2000). The long-term environmental changes observed in Frobisher Bay indicate that primary productivity or other organic matter delivery has increased in the region. This would suggest that thyasird bivalves should have persisted in similar, if not greater abundance in 2016; however, despite their great abundance historically, A. orbiculata significantly declined at station F1, the abundance of T. gouldi declined at stations F3 and F4, and T. gouldi was completely lost at stations F1 and F2 (Supplementary data, Table S4). The Iqaluit region appeared to be sandier in 2016 (Fig. 4), even though a change in sediment composition was not significant between the two time periods (this result may have been influenced by the inclusion of water depth and the interaction term in the model). In addition, individual stations did exhibit an increase in carbon:nitrogen ratio (Appendix A, Fig. A2), even though the region did not exhibit a significant change between the two time periods. These changes at the station level could have resulted in a less appealing environment for the thyasirid bivalves (Oliver et al. 2016). However, the sedimentary changes described here do not support the decline in abundance of the gastropods C. alba and R. obtusa or the bivalve E. tenuis, which are indifferent to organic enrichment and which are observed in muddy, silty, or sandy environments (Berry 1988; Knowledge Bank for Biodiversity 2021; WoRMS 2021). It is probable that localized changes in the environment not examined in this study may be responsible for the decline in these common species between the two time periods.

The common bivalves E. tenuis, $M$. discors, $N$. minuta, and $H$. arctica all declined in abundance in the Cairn Island region in 2016, but this decline was not as great as that experienced in the Iqaluit region (Table 3). No change in abundance was observed for T. gouldi, the most abundant mollusc in the Cairn Island region, whereas Macoma moesta, Nuculana pernula, Yoldia hyperborea, and C. alba increased in abundance in 2016 (Table 3). However, dissimilarity between the historical and modern samples in the Cairn Island region is only attributed to some of these common Cairn Island molluscs: M. discors, N. minuta, N. pernula, and H. arctica (Table 5). The bivalve Dacrydium vitreum also contributed to the dissimilarity between the historical and modern molluscan assemblage in this region but was not listed as a common species in the region. These five species contributed to only $25 \%$ of the dissimilarity between the historical and modern molluscan assemblages, indicating that there were several other mollusc species that influenced the historical and modern assemblages in this region. Renaud et al. (2007) examined multidecadal benthic community structure in van Mijenfjord, Spitsbergen, and suggested that there may not necessarily be any specific physical factor that drives community change where there is stability in the benthic community, whereas Gray and Christie (1983) suggested that long-term environmental cycles (e.g., periods of 3-4, 6-8, 10-12, and 18-20 years) could be responsible for the temporal variability observed in benthic communities. In their study, Gray and Christie (1983) attributed these cycles to cyclical temperature variations, the solar cycle, and long-term lunar tides in the North Atlantic, all of which can affect hydrographic conditions. These cycles can affect plankton abundance, which in turn can affect the benthos which rely on food resources from settling organic matter (Gray and Christie 1983). Powell and Cummins (1985) predicted that species life-spans control community composition to some degree. Molluscs demonstrate a variety of life spans. Life span information was available for only some of the common species in this study. For example, M. discors, T. gouldi, H. arctica, and N. minuta have a life span ranging from 3 to 10 years (Ansell et al. 1978; 
Selin 2010; BIOTIC 2019), and these species declined in abundance in either the Iqaluit or Cairn Island regions between the two time periods. Retusa obtusa has a life span of three years or less (Smith 1967) and declined in the Iqaluit region between the two time periods, whereas N. pernula has a life span of 10+ years (Ansell et al. 1978; Selin 2010), and this species slightly increased in abundance in the Cairn Island region between the two time periods. Therefore, natural cycles related to the life span of these common mollusc species could be responsible for the change in assemblages observed.

\section{Long-term change vs. short-term variability}

Despite the significant long-term environmental changes that have occurred in the region and the significant changes in sediment characteristics, diversity indices, and overall community composition between the two time periods, there are many similarities between the historical and modern molluscan assemblages. This lends to the question as to whether long-term changes in the benthos can be confirm by examining two snap-shots in time. A 50 year gap should certainly be an appropriate time scale to measure benthic community change in Frobisher Bay amid the significant environmental changes that have occurred. However, the benthic communities in Frobisher Bay did experienced dramatic seasonal and interannual changes in molluscan species richness between 1967 and 1976, and in some cases, the changes observed in 2016 fell within the range of short-term seasonal and interannual change observed in the historical data (Table 6). Cusson et al. (2007) examined short-term variability of the entire benthic community using the same infaunal dataset from Wacasey et al. $(1979,1980)$ and also observed that temporal variation in benthic assemblage was of the same magnitude or greater than spatial variation between each station examined. The implications for this study are that large seasonal and interannual variation may have masked long-term trends.

\section{Contribution of other benthic fauna in shaping molluscan assemblages}

It is likely that other organisms within the benthic infaunal community have shaped the molluscan assemblages observed among seasonal and interannual historical samples (as observed by Cusson et al. 2007) as well as between the historical and modern samples. Complex interactions among benthic infauna exist and competition and predation can have a strong influence on the structure of the benthic community (Ambrose 1984; Wilson 1991). In Arctic environments, molluscs are an important part of the food web and are preyed upon by a variety of fauna include sea stars, brittle stars, crabs, shrimp, some snail species (e.g., buccinid gastropods), and vertebrate predators including walruses, ducks, and fish (Feder et al. 1994). Unfortunately, in data-poor Arctic environments such as Frobisher Bay, studies of predator-prey dynamics are lacking, and consideration should be made for the role that other fauna may have had in shaping the molluscan assemblages in this study.

\section{Conclusions}

This study examined temporal changes in the molluscan assemblages of Frobisher Bay as a result of long-term environmental change in this region. Long-term studies are crucial to our understanding of ecological responses to natural and anthropogenic environmental change (Carpenter et al. 1995). Frobisher Bay has experienced a significant long-term increase in air temperature, a significant loss of sea ice, and a change in the hydrodynamic conditions in the Sylvia Grinnell and Apex rivers. Despite changes to the molluscan assemblages between the two time periods in both regions, including a significant decline in species richness in the Iqaluit region and a significant increase in species diversity in the Cairn Island region, both regions retained some similarities in the composition of the 
molluscan assemblages. This suggests that, despite environmental change in the region, molluscan assemblages are being maintained in inner Frobisher Bay. Changing climate conditions in this region may not be solely responsible for the assemblage changes observed in this study. Going forward, standardized and systematic sampling should be prioritized to better understand community level changes that occur in Arctic coastal molluscan communities. A consistent sampling protocol in addition to sampling at an appropriate time scale are both necessary for distinguishing between short-term fluctuations and long-term change. Conducting community analyses on short-term seasonal and interannual time scales, in addition to conducting larger-scale long-term studies, are invaluable for understanding the extent of temporal variation that exist within the community being examined. Given that natural environmental cycles occur on both short (2-3 year) and long (18-20) time scales, and given that recommendations have been made to conduct systematic long-term studies on at least decadal scales (Renaud et al. 2007), it is likely that comparing molluscan infaunal samples during two distinct time periods may have resulted in missed trends in changing community composition.

Historical datasets, however, should not be undervalued. Where consistent long-term monitoring is not possible, historical datasets are an invaluable tool with which to examine benthic Arctic communities in "pristine" conditions and can be used as benchmark datasets for future studies. Dredging for a deep sea port in the city of Iqaluit began in 2019 at the southern tip of Koojesse Inlet (Aarluk Consulting Inc. 2005; Tranter 2019) with completion of the deep sea port anticipated in 2021 (Patar 2020). Stations F1 and F2 are anticipated to be directly affected by this development. Sampling at these and surrounding stations is now needed to document this disturbance as well as the recovery of the benthos in this region. The historical infaunal data collected by Wacasey et al. (1979. 1980) and the molluscan data collected in 2016 as part of this study will both serve as invaluable benchmarks from which to document future changes in the molluscan assemblages in this region.

\section{Acknowledgements}

This project was made possible through the ArcticNet (Canadian Network of Centres of Excellence) project Integrated Marine Geoscience to Guide Environmental Impact Assessment and Sustainable Development in Frobisher Bay, Nunavut, and with a discovery grant to E. Edinger through the Natural Sciences and Engineering Research Council of Canada (NSERC). 2016 Sampling was supported by an NSERC ship-time grant, by an ArcticNet ship-time on alternate vessels grant, and by the Amundsen Science funding from the Canadian Foundation for Innovation (CFI). We would like to thank the crew of the CCGS Amundsen and RV Nulialjuk and Inuit research assistants for their support in collecting benthic samples for this project. We thank the Canada-Nunavut Geoscience Office and the Nunavut Research Institute for additional field support. We would also like to thank Jordon Rozon, Robert Deering, Ben Misiuk, Alison Pye, and Taylor Hughes for their assistance with various aspects of this project including sample processing and data management. Finally, we thank the dedicated external reviewers who provided feedback for the M.Sc. thesis version of this manuscript as well as the reviewers who provided feedback for this paper.

\section{References}

Aarluk Consulting Inc. 2005. Strategic plan for the Iqaluit deep-water port project. Prepared for the City of Iqaluit. Available from: https://www.tunngavik.com/documents/publications/2005-08-00\%20Iqaluit\%20Deepwater\%20Port \%20Strategic\%20Plan.pdf [accessed 29 January 2021].

Ambrose, W.G., Jr. 1984. Role of predatory infauna in structuring marine soft-bottom communities. Mar. Ecol. Prog. Ser. 17: 109-115. doi: 10.3354/meps017109. 
Andrews, J.T. 1972. Recent and fossil growth rates of marine bivalves, Canadian Arctic, and Late-Quaternary arctic marine environments. Palaeogeogr. Palaeoclimatol. Palaeoecol. 11: 157-176. doi: 10.1016/0031-0182(72)90064-8.

Ansell, A.D., Parulekar, A.H., and Allen, J.A. 1978. On the rate of growth of Nuculana minuta (Muller) (Bivalvia; Nuculanidae). J. Molluscan Stud. 44: 71-82. doi: 10.1093/oxfordjournals.mollus.a065418.

Arctic Laboratories Ltd. 1985. Sampling and analysis in the Arctic marine benthic environment. Vol. 1. Review of methods. Environmental Protection Service, Yellowknife, N.W.T., Canada. 661 p. Available from: http:// publications.gc.ca/collections/collection_2020/eccc/en40/En40-990-1985-1-eng.pdf.

Atkinson, E.G., and Wacasey, J.W. 1987. Sedimentation in Arctic Canada: Particulate organic carbon flux to a shallow marine benthic community in Frobisher Bay. Polar Biol. 8: 3-7. doi: 10.1007/BF00297157.

Batstone, R.T., Laurich, J.R., Salvo, F., and Dufour, S.C. 2014. Divergent chemosymbiosis-related characters in Thyasira cf. gouldi (Bivalvia: Thyasiridae). PLoS ONE, 9(3): e92856. doi: 10.1371/journal.pone.0092856. PMID: 24658402.

Berry, A.J. 1988. Annual cycle in Retusa obtusa (Montagu) (Gastropoda, Opisthobranchia) of reproduction, growth and predation upon Hydrobia ulvae (Pennant). J. Exp. Mar. Biol. Ecol. 117: 197-209. doi: 10.1016/0022-0981(88)90057-3.

Beuchel, F., and Gulliksen, B. 2008. Temporal patterns of benthic community development in an Arctic fjord (Kongsfjorden, Svalbard): results of a 24-year manipulation study. Polar Biol. 31: 913-924. doi: 10.1007/s00300008-0429-9.

Beuchel, F., Gulliksen, B., and Carroll, M.L. 2006. Long-term patterns of rocky bottom macrobenthic community structure in an Arctic fjord (Kongsfjorden, Svalbard) in relation to climate variability (1980-2003). J. Mar. Syst. 63: 35-48. doi: 10.1016/j.jmarsys.2006.05.002.

BIOTIC (Biological Traits Information Catalogue). 2019. Biological traits information catalogue. Available from http://www.marlin.ac.uk/biotic/ [accessed January 2019].

Borja, A., Franco, J., and Perez, V. 2000. A marine biotic index to establish the ecological quality of soft-bottom benthos within European estuarine and coastal environments. Mar. Pollut. Bull. 40(12): 1100-1114. doi: 10.1016/S0025326X(00)00061-8.

Boyd, S.E., Barry, J., and Nicholson, M. 2006. A comparative study of a $0.1 \mathrm{~m} 2$ and $0.25 \mathrm{~m} 2$ Hamon grab for sampling microbenthic fauna from offshore marine gravels. J. Mar. Biol. Assoc. U. K. 86: 1315-1328. doi: 10.1017| S0025315406014342.

Brown, T., Edinger, E.N., Hooper, R.G., and Belliveau, K. 2011. Benthic marine fauna and flora of two nearshore coastal locations in the Western and Central Canadian Arctic. Arctic, 64(3): 281-301. doi: 10.14430/arctic4119.

Canadian Ice Service. 2013. Sea ice climate atlas for the northern Canadian waters 1981-2010. Available from https:// www.canada.ca/en/environment-climate-change/services/ice-forecasts-observations/publications/sea-climaticatlas-northern-waters-1981-2010.html [accessed 26 August 2016].

Carmack, E., and McLaughlin, F. 2001. Arctic ocean change and consequences to biodiversity: A perspective on linkage and scale. Mem. Natl. Inst. Polar Res. 54: 365-375.

Carpenter, S.R., Chisholm, S.W., Krebs, C.J., Schindler, D.W., and Wright, R.F. 1995. Ecosystem experiments. Science, 269(5222): 324-327. doi: 10.1126/science.269.5222.324. PMID: 17841247.

Carey, J.M., and Keough, M.J. 2002. Compositing and subsampling to reduce costs and improve power in benthic infaunal monitoring systems. Estuaries, 25(5): 1053-1061. doi: 10.1007/BF02691352.

Carey, A.G., Scott, P.H., and Walters, K.R. 1984. Distributional ecology of shallow southwestern Beaufort Sea (Arctic Ocean) bivalve Mollusca. Mar. Ecol. Prog. Ser. 17: 125-134. doi: 10.3354/meps017125.

Carey, A.G. 1991. Ecology of North American Arctic continental shelf benthos: A review. Cont. Shelf Res. 11(8-10): 865-883. doi: 10.1016/0278-4343(91)90083-I.

Carroll, M.L., Denisenko, S.G., Renaud, P.E., and Ambrose, W.G., Jr. 2008. Benthic infauna of the seasonally ice-covered western Barents Sea: Patterns and relationships to environmental forcing. Deep-Sea Res. II. Top. Stud. Oceanogr. 55: 2340-2351. doi: 10.1016/j.dsr2.2008.05.022.

Carroll, M.L., Johnson, B.J., Henkes, G.A., McMahon, K.W., Voronkov, A., Ambrose, W.G., Jr., and Denisenko, S.G. 2009. Bivalves as indicators of environmental variation and potential anthropogenic impacts in the southern Barents Sea. Mar. Pollut. Bull. 59: 193-206. doi: 10.1016/j.marpolbul.2009.02.022. PMID: 19394657.

Chikina, M.V., Spiridonov, V.A., and Naumov, A.D. 2020. Modiolus modiolus communities of Onega Bay, White Sea: How stable are they over time and space? Biol. Bull. 47(9): 1099-1114. doi: 10.1134/S1062359020090058.

Clarke, A., and Crame, J.A. 2010. Evolutionary dynamics at high latitudes: speciation and extinction in polar marine faunas. Philos. Trans. R. Soc. Lond. Biol. Sci. 365(1558): 3655-3666. doi: 10.1098/rstb.2010.0270.

Clarke, K.R., and Warwick, R.M. 2001. Change in marine communities: an approach to statistical analysis and interpretation, 2nd ed. PRIMER-E, Plymouth, UK.

Clark, G.F., Stark, J.S., Palmer, A.S., Riddle, M.J., and Johnston, E.L. 2017. The roles of sea-ice, light and sedimentation in structuring shallow Antarctic benthic communities. PLoS ONE, 12(1): e0168391. doi: 10.1371/journal. pone. 0168391 .

Craft, C.B., Senica, E.D., and Broome, S.W. 1991. Loss on Ignition and Kjeldahl digestion for estimating organic carbon and total nitrogen in estuarine marsh soils: Calibration with dry combustion. Estuaries, 14(2): 175-179. doi: $10.2307 / 1351691$.

Cross, W.E., and Thomson, D.H. 1987. Effects of experimental releases of oil and dispersed oil on Arctic nearshore macrobenthos. I. Infauna. Arctic, 40(1): 184-200. doi: 10.14430/arctic1813.

Cross, W.E., Martin, C.M., and Thomson, D.H. 1987. Effects of experimental releases of oil and dispersed oil on Arctic nearshore macrobenthos. II. Epibenthos. Arctic, 40(1): 201-210. doi: 10.14430/ARCTIC1814. 
Cusson, M., Archambault, P., and Aitken, A. 2007. Biodiversity of benthic assemblages on the Arctic continental shelf: Historical data from Canada. Mar. Ecol. Prog. Ser. 331: 291-304. doi: 10.3354/meps331291.

Dimitriadis, C., and Koutsoubas, D. 2008. Community properties of benthic molluscs as indicators of environmental stress induced by organic enrichment. J. Nat. Hist. 42(5-8): 559-574. doi: 10.1080/00222930701835530.

Dyer, M.F., Cranmer, G.J., Fry, P.D., and Fry, W.G. 1984. The distribution of benthic hydrographic indicator species in Svalbard Waters, 1978-1981. J. Mar. Boil. Assess. U.K. 64: 667-677. doi: 10.1017/S0025315400030332.

Dyke, A.S., Dale, J.E., and McNeely, R.N. 1996. Marine molluscs as indicators of environmental change in glaciated North America and Greenland during the last 18,000 years. Géogr. Phys. Quat. 50(2): 125-184. doi: 10.7202/ 033087ar.

Feder, H.M., Foster, N.R., Jewett, S.C., Weingartner, T.J., and Baxter, R. 1994. Mollusks in the Northeastern Chukchi Sea. Arctic, 47: 145-163. doi: 10.14430/arctic1285.

Forbes, D.L. (ed.). 2011. State of the Arctic Coast 2010 - Scientific review and outlook. International Arctic Science Committee, Land-Ocean Interactions in the Coastal Zone, Arctic Monitoring and Assessment Programme, International Permafrost Association, Helmholtz-Zentrum, Geesthacht, Germany. 178 p. Available from https:/ www.researchgate.net/publication/264545070_State_of_the_Arctic_Coast_2010_Scientific_Review_and_Outlook.

Fox, J., and Weisberg, S. 2019. An R companion to applied regression, 3rd ed. Sage, Thousand Oaks, CA, USA.

Goossens, D. 2008. Techniques to measure grain-size distributions of loamy sediments: a comparative study of ten instruments for wet analysis. Sedimentology, 55: 65-96. doi: 10.1111/j.1365-3091.2007.00893.x.

Gorlich, K., Weslawski, J.M., and Zajaczkowski, M.1987. Suspension settling effect on macrobenthos biomass distribution in the Hornsund Fjord, Spitsbergen. Polar Res. 5(2): 175-192. doi: 10.3402/polar.v5i2.6875.

Government of Canada. 2017. Ice thickness data. Available from https://www.canada.ca/en/environmentclimate-change/services/ice-forecasts-observations/latest-conditions/archive-overview/thickness-data.html [accessed 6 December 2017].

Government of Canada. 2018a. Historical climate data. Available from http://climate.weather.gc.ca/index_e.html [accessed December 2017].

Government of Canada. 2018b. Historical hydrometric data search. Available from https://wateroffice.ec.gc.ca/ search/historical_e.html. [accessed December 2017].

Gray, J.S., and Christie, H. 1983. Predicting long-term changes in marine benthic communities. Mar. Ecol. Prog. Ser. 13: 87-94. doi: $10.3354 /$ meps013087.

Grebmeier, J.M., Overland, J.E., Moore, S.E., Farley, E.V., Carmack, E.C., Cooper, L.W., et al. 2006. A major ecosystem shift in the Northern Bering Sea. Science, 311: 1461-1464. doi: 10.1126/science.1121365. PMID: 16527980.

Grebmeier, J.M. 2012. Shifting patterns of life in the Pacific Arctic and Sub-Arctic Seas. Ann. Rev. Mar. Sci. 4: 63-78. doi: 10.1146/annurev-marine-120710-100926. PMID: 22457969.

Grebmeier, J.M., Bluhm, B.A., Cooper, L.W., Denisenko, S.G., Iken, K., Kędra, M., and Serratos, C. 2015. Time-series benthic community composition and biomass and associated environmental characteristics in the Chukchi Sea during the RUSALCA 2004-2012 Program. Oceanography, 28(3): 116-133. doi: 10.5670/oceanog.2015.61.

Heiri, O., Lotter, A.F, and Lemcke, G. 2001. Loss on ignition as a method for estimating organic and carbonate content in sediments: reproducibility and comparability of results. J. Paleolimnol. 25: 101-110. doi: 10.1023/A: 1008119611481.

Hodgson, D.A. 2005. Quaternary geology of western Meta Incognita Peninsula and Iqaluit area, Baffin Island, Nunavut. Geological Survey of Canada, Bulletin No. 582.

Holte, B., and Buhl-Mortensen, L. 2020. Does grab size influence sampled macrofauna composition? A test conducted on deep-sea communities in the northeast Atlantic. Mar. Environ. Res. 154: 104867. doi: 10.1016/ j.marenvres.2019.104867. PMID: 31928984.

Hsiao, S.I.C. 1992. Dynamics of ice algae and phytoplankton in Frobisher Bay. Polar Biol. 12: 645-651. doi: 10.1007| BF00236987.

Hsiao, S.I.C., and Pinkewycz, N. 1983. Phytoplankton data from Frobisher Bay, 1979 to 1981. Canadian Data Report of Fisheries and Aquatic Sciences, No. 419.

Hsiao, S.I.C., and Pinkewycz, N. 1985. Phytoplankton data from a 1976 cruise in Frobisher Bay. Canadian Data Report of Fisheries and Aquatic Sciences, No. 575.

Kedra, M., Wlodarska-Kowalczuk, M., and Weslawski, J.M. 2010. Decadal change in macrobenthic soft-bottom community structure in a high Arctic fjord (Kongsfjorden, Svalbard). Polar Biol. 33: 1-11. doi: 10.1007/s00300-009-0679-1.

Kiyko, O.A., and Pogrebov, V.B. 1997. Long-term benthic population changes (1920-1930s-Present) in the Barents and Kara Seas. Mar. Pollut. Bull. 35(7-12): 322-332. doi: 10.1016/S0025-326X(97)00113-6.

Knowledge Bank for Biodiversity. 2021. Species online. Available from https://artsdatabanken.no/ [accessed 2 March 2021].

Kortsch, S., Primicerio, R., Beuchel, F., Renaud, P.E., Rodrigues, J., and Lonne, O.J. 2012. Climate-driven regime shifts in Arctic marine benthos. Proc. Natl. Acad. Sci. U. S. A. 109(35): 14052-14057. doi: 10.1073/pnas.1207509109. PMID: 22891319.

Kozlovskiy, V.V., Chikina, M.V., Kucheruk, N.V., and Basin, A.B. 2011. Structure of the macrozoobenthic communities in the Southwestern Kara Sea. Oceanology, 51(6): 1012-1020. doi: 10.1134/S0001437011060087.

Kutty, M.K., and Desai, B.N. 1968. A comparison of the efficiency of bottom samplers used in benthic studies off Cochin. Mar. Biol. 1: 168-171. doi: 10.1007/BF00347106.

Loeng, L. 2005. Marine systems. In: Arctic climate impact assessment. ACIA Overview Report. Cambridge University Press. 1020 pp. Available from https:/|acia.amap.no/. 
McLaughlin, F.A., Carmack, E., Proshutinsky, A., Krishfield, R.A., Guay, C.K., Yamamoto-Kawai, M., et al. 2011. The rapid response of the Canada Basin to climate forcing: from bellwether to alarm bells. Oceanography, 24: 146-159. doi: 10.5670/oceanog.2011.66.

McMahon, K.W., Ambrose, W.G., Jr., Johnson, B.J., Sun, M.-Y., Lopez, G.R., Clough, L.M., and Carroll, M.L. 2006. Benthic community response to ice algae and phytoplankton in Ny Ålesund, Svalbard. Mar. Ecol. Prog. Ser. 310: 1-14. doi: 10.3354/meps310001.

Misiuk, B., Diesing, M., Aitken, A., Brown, C.J., Edinger, E.N., and Bell, T. 2019. A spatially explicit comparison of quantitative and categorical modelling approaches for mapping seabed sediments using random forest. Geosciences, 9: 254. doi: 10.3390/geosciences9060254.

Moss, D.K., Ivany, L.C., Silver, R.B., Schue, J., and Artruc, E.G. 2017. High-latitude settings promote extreme longevity in fossil marine bivalves. Paleobiology, 43(3): 365-382. doi: 10.1017/pab.2017.5.

Moss, D.K., Surge, D., and Khaitov, V. 2018. Lifespan and growth of Astarte borealis (Bivalvia) from Kandalaksha Gulf, White Sea, Russia. Polar Biol. 41: 1359-1369. doi: 10.1007/s00300-018-2290-9.

Natural Earth. 2020. Free vector and raster map data at 1:10m, 1:50m, and 1:110m scales. Available from https:// www.naturalearthdata.com/.

Novoa, A., Talley, T.S., Talley, D.M., Crooks, J.A., and Reyns, N.B. 2016. Spatial and temporal examination of bivalve communities in several estuaries in southern California and northern Baja California, MX. PLoS ONE, 11(3): e0151727. doi: 10.1371/journal.pone.0148220. PMID: 26967523.

Ockelmann, W.K. 1958. The zoology of East Greenland, marine Lamellibranchiata. Medd. Gronland, 122: 1-256.

Oliver, P.G., Holmes, A.M., Killeen, I.J., and Turner, J.A. 2016. Marine Bivalve Shells of the British Isles. Amgueddfa Cymru - National Museum Wales. Available from http://naturalhistory.museumwales.ac.uk/britishbivalves [accessed 11 January 2018].

Overeem, I., Anderson, R.S., Wobus, C.W., Clow, G.D., Urban, F.E., and Matell, N. 2011. Sea ice loss enhances wave action at the Arctic coast. Geophys. Res. Lett. 38: L17503. doi: 10.1029/2011GL048681.

Overland, J.E., Hanna, E., Hanseen-Bauer, I., Kim, S.-J., Walsh, J.E., Wang, M., et al. 2017. Surface air temperature. In Arctic Report Card 2017. Edited by J. Richter-Menge, J.E. Overland, J.T. Mathis, and E. Osborne. Available from http://www.arctic.noaa.gov/Report-Card.

Patar, D. 2020. Iqaluit deepsea port project remains on schedule for 2021 completion. Nunatsiaq News, 13 October 2020. Available from https://nunatsiaq.com/stories/article/iqaluit-deepsea-port-project-remains-on-schedule-for2021-completion/ [accessed 29 January 2021].

Piepenburg, D. 2005. Recent research on Arctic benthos: Common notions need to be revised. Polar Biol. 28: 733-755. doi: 10.1007/s00300-005-0013-5.

Powell, E.N., and Cummins, H. 1985. Are molluscan maximum life spans determined by long-term cycles in benthic communities? Oecologia, 67: 177-182. doi: 10.1007/BF00384281. PMID: 28311306.

Renaud, P.E., Wlodarska-Kowalczuk, M., Trannum, H., Holte, B., Weslawski, J.M., Cochrane, S., et al. 2007. Multidecadal stability of benthic community structure in a high-Arctic glacial fjord (van Mijenfjord, Spitsbergen). Polar Biol. 30: 295-305. doi: 10.1007/s00300-006-0183-9.

Renaud, P.E., Sejr, M.K., Bluhm, B.A., Sirenko, B., and Ellingsen, I.H. 2015. The future of Arctic benthos: Expansion, invasion, and biodiversity. Prog. Oceanogr. 139: 244-257. doi: 10.1016/j.pocean.2015.07.007.

Richter-Menge, J., Overland, J.E., Mathis, J.T., and Osborn, E. (eds.). 2017. Arctic report card 2017. Available from http://www.arctic.noaa.gov/Report-Card.

Romano, E., Magno, M.C., and Bergamin, L. 2017. Grain size data analysis of marine sediments, from sampling to measuring and classifying, A critical review. IMEKO International Conference on Metrology for The Sea, Naples, Italy, 11-13 October 2017. pp. 174-178. Available from https://www.imeko.org/publications/tc19-Metrosea-2017/ IMEKO-TC19-METROSEA-2017-33.pdf.

Rumolo, P., Barra, M., Gherardi, S., Marsella, E., and Sprovieri, M. 2011. Stable isotopes and C/N ratios in marine sediments as a tool for discriminating anthropogenic impact. J. Environ. Monitor. 13: 3399-3408. doi: 10.1039/ c1em10568j.

R Studio Team. 2020. RSTudio: Integrated development for R. RStudio, PBC, Boston, MA, USA. Available from http:// www.rstudio.com/.

Selin, N.I. 2010. The growth and life span of bivalve mollusks at the Northeastern coast of Sakhalin Island. Russ. J. Mar. Biol. 36(4): 258-269. doi: 10.1134/S1063074010040048.

Smith, S.T. 1967. The ecology and life history of Retusa obtusa (Montagu) (Gastropoda, Opisthobranchia). Can. J. Zool. 45: 397-405. doi: 10.1139/z67-051.

Stasko, A.D., Bluhm, B.A., Michel, C., Archambault, P., Majewski, A., Reist, J.D., et al. 2018. Benthic-pelagic trophic coupling in an Arctic marine food web along vertical water mass and organic matter gradients. Mar. Ecol. Prog. Ser. 594: 1-19. doi: 10.3354/meps12582.

Taylor, J., Krumpen, T., Soltwedel, T., Gutt, J., and Bergmann, M. 2017. Dynamic benthic megafaunal communities: Assessing temporal variations in structure, composition and diversity at the Arctic deep-sea observatory HAUSGARTEN between 2004 and 2015. Deep-Sea Res. I Oceanogr. Res. Pap. 122: 81-94. doi: 10.1016/ j.dsr.2017.02.008.

Thrush, S.E., Hewitt, J.E., Cummings, V.J., Ellis, J.I., Hatton, C., Lohrer, A., and Norkko, A. 2004. Muddy waters: Elevating sediment input to coastal and estuarine habitats. Front. Ecol. Environ. 2(6): 299-306. doi: 10.1890/15409295(2004)002[0299:MWESIT]2.0.CO;2. 
Thurstan, R.H., McClenachan, L., Crowder, L.B., Drew, J.A., Kittinger, J.N., Levin, P.S, et al. 2015. Filling historical data gaps to foster solutions in marine conservation. Ocean Coast. Manage. 115: 31-40. doi: 10.1016/ j.ocecoaman.2015.04.019.

Tranter, E. 2019. Construction set to resume for Iqaluit's small-craft harbor and deepsea port. Nunatsiaq News. Printed 27 May 2019. Available from https://nunatsiaq.com/stories/article/construction-set-to-resume-for-iqaluitssmall-craft-harbour-and-deepsea-port/.

Tremblay, T., Kamula, C.M., Ciastek, S., and Zukyk, Z.A., 2020. Overview of the geochemical properties of the marine sediments of Koojesse Inlet, Frobisher Bay, Nunavut. Canada-Nunavut Geoscience Office Summary of Activities 2019, pp. 125-144. Available from Summary of Activities 2019 - Canada-Nunavut Geoscience Office (cngo.ca).

Wacasey, J.W., Atkinson, E.G., and Glasspoole, L. 1979. Zoobenthos data from upper Frobisher Bay, 1967-1973. Canadian Data Report of Fisheries and Aquatic Sciences, No. 164.

Wacasey, J.W., Atkinson, E.G., and Glasspoole, L. 1980. Zoobenthos data from inshore stations of upper Frobisher Bay 1969-1976. Canadian Data Report of Fisheries and Aquatic Sciences, No. 205.

Wang, J.-P., Wang, X-J., and Zhang, J. 2013. Evaluating loss-on-ignition method for determinations of soil organic and inorganic carbon in arid soils of Northwestern China. Pedosphere, 23(5): 593-599. doi: 10.1016/S10020160(13)60052-1.

Wassmann, P., and Reigstad, M. 2011. Future Arctic ocean seasonal ice zones and implications for pelagic-benthic coupling. Oceanography, 24(3): 220-231. doi: 10.5670/oceanog.2011.74.

Wassmann, P., Duarte, C.M., Agusti, S., and Sejr, M.K. 2011. Footprints of climate change in the Arctic marine ecosystem. Global Change Biol. 17: 1235-1249. doi: 10.1111/j.1365-2486.2010.02311.x.

Wilson, W.H. 1991. Competition and predation in marine soft-sediment communities. Ann. Rev. Ecol. Syst. 21: 221-241. doi: 10.1146/annurev.es.21.110190.001253.

Wlodarska-Kowalczuk, M. 2007. Molluscs in Kongsfjorden (Spitsbergen, Svalbard): A species list and patterns of distribution and diversity. Polar Res. 26: 48-63. doi: 10.1111/j.1751-8369.2007.00003.x.

Wlodarska-Kowalczuk, M., Pearson, T.H., and Kendall, M.A. 2005. Benthic response to chronic natural physical disturbance by glacial sedimentation in an Arctic fjord. Mar. Ecol. Prog. Ser. 303: 31-41. doi: 10.3354/meps303031.

WoRMS (World Register of Marine Species). 2021. World register of marine species. Available from http:// www.marinespecies.org/.

Zuur, A.F., Ieno, E.N., and Elphick, C.S. 2010. A protocol for data exploration to avoid common statistical problems. Methods Ecol. Evol. 1: 3-14. doi: 10.1111/j.2041-210X.2009.00001.x.

\section{Appendix A}

Fig. A1. Species-accumulation curves (chao) for pooled historical and modern benthic samples collected in Frobisher Bay between 1967 and 1976 and 2016. The grey shaded areas represent the standard deviation around the values.

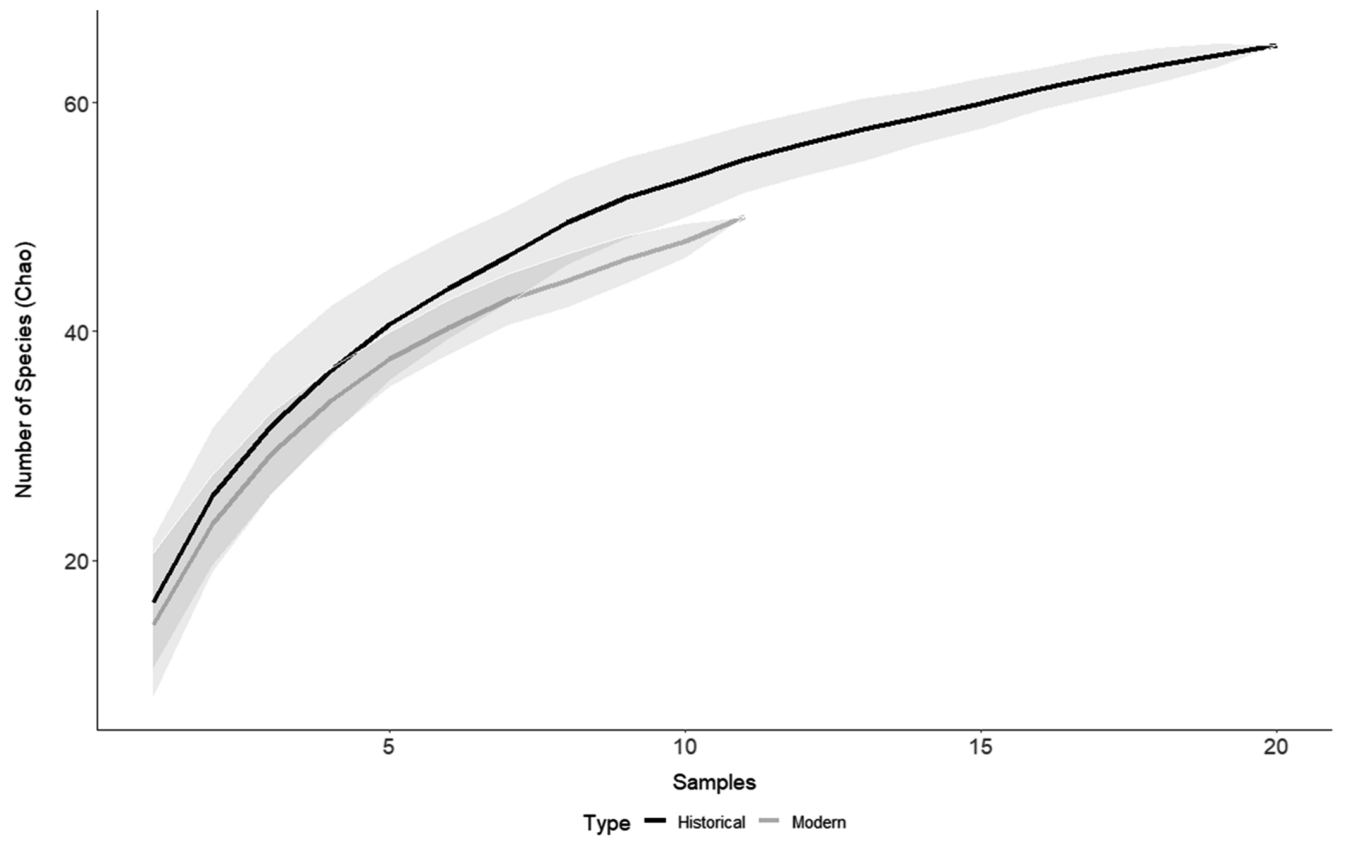


Fig. A2. Mean carbon:nitrogen ratios with standard error for each station sampled in the Iqaluit and Cairn Island regions of Frobisher Bay. Data points represent the range of carbon:nitrogen ratio values measured at each station between 1967 and 1976 (historical) and in 2016 (modern). For historical samples, the range of points at each station reflect the carbon:nitrogen ratio each time that station was sampled between 1967 and 1976 . For modern samples, points represent the carbon:nitrogen ratio for each replicate grab sample collected at each station.

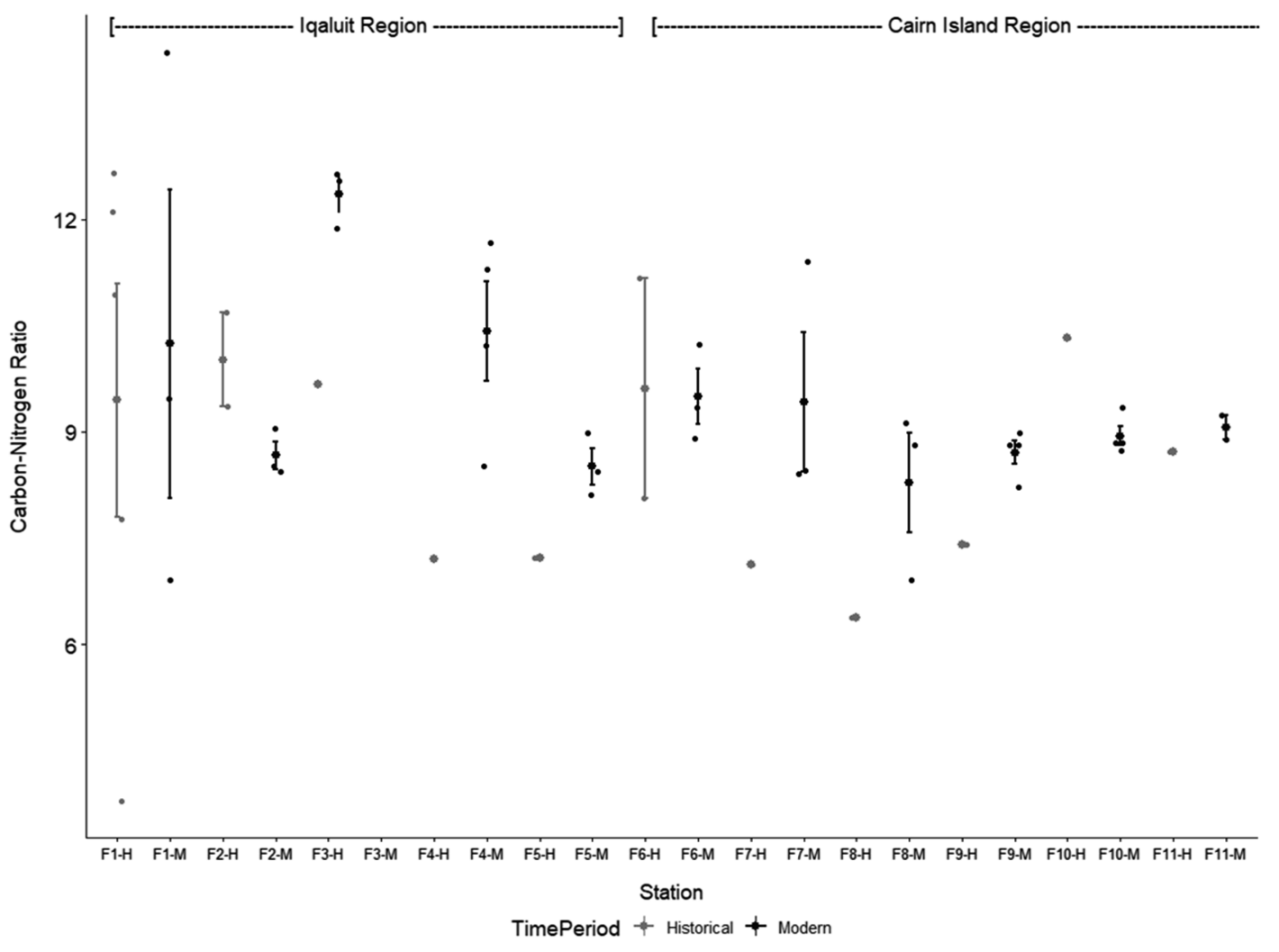

Published by Canadian Science Publishing 